HID 42 (2015)

\title{
LA GUERRA Y LA PAZ EN LA FRONTERA DE GRANADA DURANTE EL REINADO DE ALFONSO X
}

\author{
WAR AND PEACE IN THE GRANADA FRONTIER IN THE REIGN OF \\ KING ALFONSO X
}

\author{
José María Alcántara Valle \\ Universidad de Sevilla \\ jalcantara7@us.es
}

RESUMEN: De todos es bien conocida la labor cultural de Alfonso X el Sabio, pero tal vez no lo sea tanto su faceta como rey guerrero, que también fue. Con el artículo que el lector tiene en sus manos pretendemos poner de relieve la incisiva y decisiva actividad militar desplegada por este monarca, antes y después de la revuelta mudéjar de 1264-1266, y su importante contribución a la Reconquista. Analizando pormenorizadamente dicha actividad, trataremos de demostrar la prevalencia de los tiempos de guerra sobre los de paz en los años que duró su reinado.

Palabras ClaVe: Reconquista, siglo XIII, Reino de Castilla, frontera de Granada, guerra, paz.

Abstract: Not only should Alfonso X "the Wise" be remembered for his great work in all aspects of cultural life, but also for being constantly engaged in warfare. The purpose of this essay is to show the aggressive and decisive military activity carried out by this monarch before and after the Mudejar revolt in 12641266, and his important contribution to the Reconquest. By analyzing the above mentioned activity in detail, we will conclude that the periods of war were longer than the periods of peace during the time of his reign.

KEYwORDS: Reconquest, $13^{\text {th }}$ Century, Kingdom of Castile, Granada frontier, war, peace.

Alfonso X subió al trono el 1 de junio de 1252. Desde 1224 su padre había estado combatiendo contra los musulmanes en tierras andaluzas ${ }^{1}$, y desde 1240 lo había hecho él mismo en calidad de infante heredero de Castilla ${ }^{2}$. Es cierto que

1. G. Martínez Díez. Fernando III, 1217-1252. Palencia, 1993, pp. 73-77. Véase también M. González Jiménez. Fernando III el Santo. El rey que marcó el destino de España. Sevilla, 2006, pp. 86-89.

2. La Primera Crónica General alude en un confuso capítulo a la presencia en tierras cordobesas en torno a 1240 y 1241 de los infantes don Alfonso y don Fernando, que por esos años "escomençauan 
el Pacto de Jaén de 1246 supuso el inicio de un periodo de paz entre cristianos y nazaríes respetado por ambas partes hasta la sublevación mudéjar de $1264^{3}$. Pero incluso durante ese largo espacio no cesaron los enfrentamientos entre castellanos y musulmanes no granadinos. La conquista de Sevilla en 1248, la campaña militar organizada contra Jerez en 1253 o la toma de Niebla en 1262 son sólo algunos ejemplos.

La revuelta protagonizada por los mudéjares andaluces y murcianos, alentada desde Granada por Muhammad I, desencadenó en la primavera de 1264 una guerra muy sangrienta que durante dos años mantuvo en vilo a la Frontera. Después de esta ruptura, nunca más se hablaría de pactos o pleitesías entre castellanos y granadinos. Más tarde, entre 1272 y 1273, tuvo lugar en Castilla una rebelión nobiliaria dirigida contra la Corona encabezada por el infante don Felipe, hermano del propio monarca, y por don Nuño González de Lara, el primer magnate del reino, quienes no dudaron en pedir asilo a Muhammad I para atacar desde Granada a las tropas de Alfonso X. Apenas solucionado este conflicto, comenzarían a desembarcar en Tarifa y Algeciras ejércitos benimerines dispuestos a invadir Andalucía $\mathrm{y}$, de hecho, corrieron su tierra sistemáticamente entre 1275 y $1285^{4}$. La batalla de Moclín de 1280 es un hito en esa década de incesantes enfrentamientos entre Castilla y el Islam.

A tenor de lo arriba expuesto podríamos inferir, en principio, que durante el reinado de Alfonso X el tiempo de la guerra superó con creces al de la paz. Ésta es precisamente la tesis que trataremos de demostrar en las páginas siguientes.

Ahora bien, eso no quiere decir que no se firmaran treguas en la Frontera y hubiera, consecuentemente, períodos de paz. Y, en todo caso, una cosa fue la relación oficial entre los Estados, y otra muy distinta la relación personal entre los individuos. No debe extrañarnos, por tanto, que aún en tiempos de guerra y conflicto se dieran episodios de buenas relaciones entre moros y cristianos en la frontera de Granada, como también analizaremos.

entonçes a ser mançebos et auíen sabor de salir et cometer grandes fechos commo su padre el rey don Fernando et commo fizieron los reys sus auuelos donde vinien; et corrieron tierra de moros a todas partes, et robaron et quebrantaron et fezieron quanto quisieron". R. Menéndez Pidal (ed.). Primera Crónica General de España. Madrid, 1977, tomo II, pp. 735b-736a.

3. Sobre el Pacto de Jaén véase A. García Sanjuán. "Consideraciones sobre el pacto de Jaén de 1246”, M. González Jiménez (coord.). Sevilla, 1248. Congreso Internacional Conmemorativo del 750 Aniversario de la Conquista de la Ciudad de Sevilla por Fernando III, Rey de Castilla y León. Madrid, 2000, pp. 715-722.

4. Entiéndase Andalucía en el sentido en que se entendió durante los siglos XIII al XIX, es decir, como los territorios del valle del Guadalquivir conquistados por Fernando III y Alfonso X, y agrupados en torno a tres divisiones o reinos de los que fueron cabeceras las ciudades de Jaén, Córdoba y Sevilla. Véase sobre esta cuestión M. González Jiménez. Andalucía a debate y otros estudios. Sevilla, 1998, pp. 85-96, y, del mismo autor, "Andalucía, una realidad histórica", II Jornadas sobre el habla andaluza. El español hablado en Andalucía. Estepa, 2003, pp. 27-43. 


\section{El TIEMPO DE LA GUERRA. LA VIOLENCIA}

\subsection{El sistema estructural defensivo}

Todo el vasto sistema poliorcético articulado mediante la existencia de tres líneas de fortificaciones defensivas se organizaba atendiendo a dos modelos de estructura, una paralela general y otra radial. La estructura paralela general resulta de la yuxtaposición, más o menos arbitraria, de las tres líneas fortificadas que descendían escalonadamente desde el valle del Guadalquivir hasta las primeras estribaciones de los montes Subbéticos y, a su vez, ascendían de suroeste a noreste, desde Tarifa a Cazorla y Segura, paralelas siempre a la frontera geográfica ${ }^{5}$.

La estructura radial, por su parte, obedecía principalmente a las necesidades defensivas propias de cada reino y, en este sentido, cada uno se encargó de la protección de su respectivo sector fronterizo. Se pretendía con ello un auxilio más rápido y eficaz ante el peligro cotidiano, dejando únicamente para ocasiones muy excepcionales la unificación bajo un solo mando de las fuerzas militares de los tres reinos ${ }^{6}$.

Estas estructuras espaciales se articulaban a través de una serie de fortificaciones que podían ser de tres tipos: ciudades-base y villas-base del valle del Guadalquivir ${ }^{7}$, fortificaciones de la segunda línea de frontera (castillos urbanizados y ciudadelas) ${ }^{8}$, y fortificaciones de la primera línea defensiva (castillos refugios, torres defensivas y atalayas almenaras) $)^{9}$.

5. M. García Fernández. Andalucía: Guerra y Frontera, 1312-1350. Sevilla, 1990, p. 103. Sobre sistemas poliorcéticos véase también F. García Fitz. Castilla y León frente al Islam. Estrategias de expansión y tácticas militares (siglos XI-XIII). Sevilla, 1998, pp. 190-193.

6. M. García Fernández. Andalucía: Guerra y Frontera, 1312-1350, ob. cit., p. 103.

7. Se trataba de las tres grandes ciudades del valle (Sevilla, Córdoba y Jaén) y de núcleos menores de poblamiento (Jerez de la Frontera, Carmona, Écija, Arjona, Andújar, Baeza o Úbeda) que sirvieron de base a los castillos de la segunda línea fronteriza. Dotadas de potentísimas murallas y efectivas guarniciones castrenses, estas ciudades y villas de retaguardia constituyeron auténticos centros logísticos de apoyo táctico-militar en la defensa de sus respectivos reinos.

8. Los castillos urbanizados (asociados a un hábitat rural permanente) eran fortalezas considerables que disponían de fuerte amurallamiento, foso, portillos, aljibes, patio de armas y torre del homenaje. Las ciudadelas o castillos cotas consistían en pequeños fortines urbanos (alcazabas) ubicados en sitios altos y preferentes de la villa para facilitar su aislamiento en caso de peligro. Estas plazas fuertes tenían autonomía suficiente para resistir durante algún tiempo en caso de ataque y, aún así, se hallaban rodeadas de baluartes defensivos auxiliares, como atalayas y castillos aislados próximos.

9. Esta primera línea de fortificaciones defensivas estaba compuesta por un sinfín de pequeñas construcciones fortificadas distribuidas por toda la frontera de Granada. Para el siglo XIII, los análisis tipológicos permiten diferenciar entre castillos refugios ubicados en zonas rurales de itinerario y torres defensivas. Los castillos refugios eran edificaciones fortificadas aisladas, es decir, completamente disociadas de los sectores habitados más próximos, en las que la existencia de un aljibe o cisterna hacía posible la autodefensa de una guarnición militar permanente de soldados fronteros, que alternaban las funciones estrictamente militares con otras actividades de supervivencia. Las torres defensivas, por otro lado, constituyen los baluartes más significativos de la primera línea de frontera. Se trataba de construcciones muy sencillas: simples torreones de base circular o rectangular, de dos o tres plantas abovedadas y con una terraza almenada. Dentro de este tipo de arquitectura militar cabe resaltar las atalayas almenaras, esto es, torres ópticas distribuidas estratégicamente en el espacio desde las cuales 
En este contexto geográfico, las necesidades de liquidar las campañas de conquista efectuadas por Fernando III en el valle del Guadalquivir y recompensar a los caballeros por los servicios militares prestados a la Corona, de repoblar un espacio amplio y peligroso, carente a todas luces de efectivos humanos, y, por último, y sobre todo, de garantizar la defensa de una marca muy vulnerable, expuesta a sufrir los efectos de las algaras granadinas y norteafricanas, obligaron a Alfonso X a convertir en señoríos nobiliarios muchas de las plazas situadas en las tres líneas de defensa antes descritas. No nos extenderemos en el fenómeno de la concesión de dominios en la Frontera durante la segunda mitad del siglo XIII porque ya fue objeto de nuestro interés en otro trabajo ${ }^{10}$. Pero sí queremos resaltar que el Rey Sabio confirió más de medio centenar de encomiendas fronterizas a instituciones nobiliarias y miembros de la nobleza, entre los que se pueden establecer claramente cuatro categorías: familiares del rey, ricoshombres y caballeros castellanos y leoneses, sedes episcopales y órdenes militares ${ }^{11}$.

Entre los familiares del monarca que recibieron tenencias fronterizas (la reina doña Juana de Ponthieu, la reina doña Violante de Aragón y el infante don Pedro, tercer hijo de Alfonso X) se registran un total de ocho señoríos. Los ricoshombres castellanos y leoneses (don Sancho Martínez de Jódar, don Diego Sánchez de Funes, don Nuño González de Lara, don Gonzalo Yáñez Dovinal, don Bretón, don Per del Castel y don Pay Arias de Castro) recibieron, en conjunto, doce tenencias. Las sedes episcopales (Iglesia de Toledo, Iglesia de Jaén, Iglesia de Sevilla e Iglesia de Cádiz) se beneficiaron, también en su conjunto, de una decena de señoríos. Finalmente, a las órdenes militares (Santiago, Calatrava, Alcántara y Santa María de España) se les otorgó más de treinta encomiendas en la frontera de Granada.

Como se puede observar, el brazo nobiliario que salió mejor parado de la entrega de señoríos fronterizos fue el de las órdenes militares. No es de extrañar, si tenemos en cuenta que éstas nacieron para combatir al Islam y que la finalidad última de dichas concesiones era, precisamente, la defensa del territorio. En este sentido, la sublevación mudéjar de 1264, la invasión benimerín de 1275 y el malogrado sitio de Algeciras de 1278 -episodios todos ellos de los que daremos buena cuenta en el apartado que sigue- otorgaron a las órdenes militares un nuevo protagonismo en la defensa de la frontera, tanto en Murcia como en Andalucía, protagonismo cuya naturaleza y razones de fondo analizaremos al término de este trabajo ${ }^{12}$.

la guarnición destacada alertaba a las poblaciones del interior de la presencia de ejércitos enemigos por medio de ahumadas durante el día y fuego por la noche. La avanzada posición de estos baluartes defensivos hacía de los mismos auténticos presidios militares.

10. J.M. Alcántara Valle. "Nobleza y señoríos en la frontera de Granada durante el reinado de Alfonso X. Aproximación a su estudio", Vínculos de Historia, Revista del Departamento de Historia de la Universidad de Castilla-La Mancha, 2 (2013), pp. 207-232.

11. En relación a este fenómeno, Alfonso X no sólo otorgó nuevos dominios fronterizos a la nobleza, sino que también confirmó -y en algún caso modificó- la mayoría de las donaciones señoriales que había hecho su padre años atrás.

12. Resulta significativo que algunas de las plazas más peligrosas e importantes de la primera y segunda líneas de frontera fueran entregadas a las órdenes militares justo después de esas fechas: 


\subsection{Las operaciones militares}

El reinado de Alfonso X fue un reinado largo y complejo, y sobre todo, un reinado marcado por la lucha contra el Islam. En efecto. Es archiconocida la capacidad intelectual y cultural del Rey Sabio, pero quizás no lo sea tanto su manifiesta preocupación por la guerra. A continuación nos proponemos describir cronológicamente los acontecimientos bélicos, cualquiera que sea su naturaleza ${ }^{13}$, protagonizados por cristianos y musulmanes en la frontera de Granada entre 1252 y 1284, que son los años que comprende su reinado. Y lo haremos, en la medida de lo posible, siguiendo la Crónica del propio monarca, rica como ninguna en descripciones de sucesos de esta índole.

Apenas subido al trono, el Rey Sabio "basteçió e requirió las villas e lugares e castillos que eran frontera de moros" 14 , consciente del peligro que entrañaba la cercanía del Islam. Esta cercanía amenazaba no sólo a los enclaves fronterizos de la primera línea, sino también a núcleos importantes como "aquella çibdat de Seuilla", que a la altura de 1253 se encontraba "muy guerreada e non segura et los pobladores della eran muy corridos de los moros muy a menudo e reçebían muchos dannos"15. La manifiesta situación de inseguridad en la que se encontraba Sevilla, dada su proximidad a una serie de plazas en poder aún de los almohades, llevó al monarca a conquistar el pequeño reino de Tejada, en el Aljarafe, y otros lugares de la zona en $1253^{16}$. Ese mismo año, Alfonso X, "aviendo voluntad de seruir a Dios faziendo mal e danno a los moros" 17 , se propuso "conquerir la villa de Xerez", y con tal propósito "tóuola çercada vn mes"18. La campaña militar dirigida contra Jerez en la primavera de 1253 no sólo permitió al rey castellano hacerse con el control de su alcázar, sino también de aquellos enclaves islámicos de la bahía gaditana que a la muerte del Rey Santo habían pretendido liberarse de la tutela cristiana: la ciudad de Cádiz debió quedar completamente destruida y abandonada, y la alquería de Alcanate (hoy El Puerto de Santa María) pasó de

Osuna a Calatrava en 1264, Estepa a Santiago en 1267, Morón y Cote a Alcántara en 1279, y Medina Sidonia y Alcalá de los Gazules a Santa María de España, orden fundada por el propio Rey Sabio, también en 1279 .

13. Una mirada rápida a la guerra medieval, y específicamente a la fronteriza, nos permite diferenciar, por los menos, cuatro tipos de agresiones: el cerco, la cabalgada, la batalla y el apellido.

14. M. González Jiménez (edición, transcripción y notas). Crónica de Alfonso X. Según el Ms. II/2777 de la Biblioteca del Palacio Real (Madrid). Murcia, 1999, p. 7. En adelante, Crónica.

15. Crónica, p. 9.

16. A decir del cronista, los ataques procedían tanto de Tejada como de Jerez y de Niebla, y es posible que Alfonso X decidiera comenzar las conquistas de esos enclaves por el punto más débil a fin, quizás, de dar un escarmiento a los demás. Véase F. García Fitz. "Alfonso X y sus relaciones con el Emirato granadino: política y guerra”, Alcanate. Revista de Estudios Alfonsíes, 4 (2004-2005), El Puerto de Santa María, 2005, p. 46.

17. En éste y en otros muchos pasajes de la Crónica, así como en la Primera Crónica General, las Cantigas y algunos documentos expedidos por la cancillería alfonsí, se pone de manifiesto el profundo rechazo que el Rey Sabio sintió hacia el Islam. Y es lógico que así fuese: en el siglo XIII, un siglo de cruzadas, una de las mejores maneras de demostrar el amor a Dios y a su Madre era combatir y, en la medida de lo posible, aniquilar a los infieles y, entre ellos, a los musulmanes.

18. Crónica, p. 12. 
nuevo a depender de Castilla $^{19}$. Simultáneamente a estas operaciones, un hermano del rey, el infante don Enrique, ocupaba las plazas de Arcos y Lebrija. Al año siguiente, en 1254, Alfonso X expulsaba a la fuerza a los mudéjares de la villa de Morón ${ }^{20}$ y en 1255 hacía lo mismo con los de Arcos de la Frontera ${ }^{21}$.

La secuencia de enfrentamientos contra el Islam se reanuda en 1257, cuando el monarca puso en marcha la cruzada ad partes Africanas, llamada por él mismo el fecho de allende. Se trataba de proseguir la reconquista por el norte de África ${ }^{22}$,

19. Jerez y otros núcleos del valle del Guadalete, como la alquería de Alcanate, e incluso la propia ciudad de Cádiz, habían quedado sometidas después de 1248 a Fernando III mediante vínculos vasalláticos o tributarios, o una combinación de ambos. Sin embargo, la política de garantizar la seguridad de la ciudad de Sevilla y, sobre todo, el intento de estas localidades por librarse de la tutela castellana tras la muerte del Rey Santo serían los motivos que llevaron a Alfonso X a organizar una campaña militar contra esta comarca. Véase M. González Jiménez. "Una noble çibdat e bona: fundación y poblamiento de El Gran Puerto de Santa María por Alfonso X El Sabio”, Alcanate. Revista de Estudios Alfonsíes, 1 (1998-1999), El Puerto de Santa María, 1999, pp. 20-23.

20. En noviembre de 1254 Gonzalo Vicente, alcalde del rey y de Sevilla, llegaba a un compromiso con el alcalde moro Abén Çabah, en virtud del cual los mudéjares se obligaban a vender a los repobladores cristianos todas sus propiedades (casas, viñas, higuerales, olivares y huertas) y entregar al rey toda la tierra de labor, para trasladarse después en masa a la aldea de Silebar o Silibar, situada al oeste del abandonado Cote el viejo, con la prohibición de hacer "fortaleça ninguna en el castiello de Silebar, si non un corral en que se amparen que les non fagan mal". A cambio se les respetaría la estructura tradicional de su aljama con sus propias autoridades, sus leyes y sus costumbres, la libertad de movimientos, e incluso podrían tener baños, tiendas, hornos, molinos y alhóndigas "a la costunbre de los moros". La colaboración del alcayad Çabah fue recompensada con la entrega de unas casas en Sevilla, en la collación de San Bartolomé, y la garantía de que tanto él como diez de sus familiares conservarían las casas y tierras que poseían en Morón. Pero la historia de los musulmanes moronenses no se agotó en esta operación. En 1255 Alfonso X concedió a la Orden de Calatrava la alquería de Silibar, con la condición habitual de que se les respetasen a los moros "sus fueros et sus derechos". No sirvió para nada: al año siguiente ya no quedaban mudéjares en la aldea. Véase sobre este asunto M. González Jiménez y M. García Fernández (ed.). Actas Capitulares de Morón de la Frontera (1402-1426). Sevilla, 1992, p. xxiii. Véase también M. González Jiménez (ed.). Diplomatario Andaluz de Alfonso X. Sevilla, 1991, doc. núm. 139 (p. 151), doc. núm. 147 (pp. 158-160), doc. núm. 150 (pp. 161-162), doc. núm. 181 (p. 202), doc. núm. 189 (pp. 210-211) y doc. núm. 270 (pp. 298-299). En adelante, Diplomatario.

21. Al igual que ocurrió en Morón y Cote, los moros de Arcos fueron forzosamente desplazados a las aldeas del término. Véase sobre ello M. González Jiménez. "Conquista y repoblación de Arcos de la Frontera", Actas del I Congreso de Historia de Arcos de la Frontera (congreso conmemorativo del 750 aniversario de la conquista de la ciudad por Alfonso X el Sabio, 1253-2003). Cádiz, 2003, pp. 11-29. Este trabajo fue reeditado con el mismo título en M. González Jiménez. La repoblación del Reino de Sevilla en el siglo XIII. Granada, 2008, pp. 167-196 (ver aquí p. 179).

22. La idea de proseguir la conquista por el norte de África no era desde luego suya, sino de su padre, quien, a decir de la Primera Crónica General, "allen mar tenie oio para pasar et conquerir lo allá desa parte que la morisma ley tenie, ca los de acá en su poder los tenie". En efecto, Fernando III murió convencido de que el poder musulmán en la Península Ibérica tenía los días contados. Tanto es así que en su mente rondaba la idea de proseguir la reconquista por el norte de África. La citada Crónica narra a propósito de esta pretensión que, estando ya en el lecho de muerte, el monarca se dirigió a su hijo y sucesor para comunicarle, refiriéndose a la tierra por él ganada a los musulmanes, lo siguiente: "si en este estado en que yo te la dexo la sopieres guardar, eres tan buen rey como yo: et si ganares por ti más, eres meior que yo: et si desto menguas, non eres tan bueno como yo". En este contexto, la expresión "si ganares por ti más [tierras], eres meior que yo", ha sido interpretada por no pocos especialistas como una incitación a proseguir la cruzada por el Magreb, como de hecho intentaría Alfonso X en 1257. Es más, existe constancia documental de que tras la conquista de Sevilla y antes de 1253 los ceutíes pagaban algún tipo de tributo al rey de Castilla, con lo que, de alguna manera, el fecho 
una vez hubo acabado con todos los poderes islámicos residuales del Aljarafe y, sobre todo, del Guadalete y de la bahía de Cádiz, que actuaría como base de las campañas navales. La expedición contra el Magreb, preparada durante el año anterior $^{23}$, se saldó con la ocupación de la fortaleza de Tagunt, en 1257, y de la ciudad portuaria de Salé, en 1260. La escuadra cristiana que saqueó ésta última estuvo capitaneada por el adelantado mayor de la mar Juan García de Villamayor ${ }^{24}$, cuya guarnición permaneció en la plaza durante los días 8 al 22 de septiembre de $1260^{25}$.

A la vista del éxito obtenido, Alfonso X convocó Cortes en enero de 1261 para recabar un servicio extraordinario que le permitiese continuar el fecho de África ${ }^{26}$. Por las razones que fuese, la campaña así organizada se dirigió finalmente no contra el adversario marroquí sino contra el reino vasallo de Niebla, regido por Muhammad Ibn Mahfuz. 1261 fue desde luego un año clave en la lucha contra el Islam, habida cuenta los hechos acontecidos: la entrega del alcázar de Jerez por parte del reyezuelo local Abén Abit y el inicio del cerco de Niebla. Por lo que hace al primer asunto, Jerez era desde los tiempos del rey don Fernando una especie de protectorado musulmán de Castilla que Alfonso X más o menos respetó y mantuvo hasta 1261. Sin embargo, ese año el rey resolvió conquistar definitivamente la plaza ${ }^{27}$, que sería vinculada a don Nuño González de Lara. Éste a su vez, como era usual en la época, confió la fortaleza jerezana a un vasallo suyo llamado Garci Gómez Carrillo ${ }^{28}$. En julio de 1261, por otra parte, se inició el cerco de la villa de Niebla, "la primera que ganamos después que regnamos", como afirma un

de allende ya lo había iniciado Fernando III en vida. Véase R. Menéndez Pidal (ed.), Primera Crónica General de España, tomo II, ob. cit., pp. 772b y 773a. Véase también M. González Jiménez, Alfonso X el Sabio, 1252-1284. Palencia, 1993, p. 43. Y véase, por último, J.M. Rodríguez García, "La marina alfonsí al asalto de África (1240-1280). Consideraciones estratégicas e historia", Revista de Historia Naval, 85 (2004), p. 46.

23. El 8 de septiembre de 1256 Alfonso X ordenaba a don Gonzalo Vicente, alcalde mayor de Sevilla, "que acomodase a los caballeros de su mesnada y de la de su padre, y a los infantes sus hermanos, que habia mandado llamar para la guerra que había de hacer a los moros”. ¿A qué guerra se estaba refiriendo el rey? Evidentemente, a la de África (Diplomatario, doc. núm. 183 (p. 203)).

24. Don Juan García de Villamayor era hermano de don Alfonso García de Villamayor, adelantado mayor de Murcia entre 1258 y 1261, y adelantado mayor de Murcia y Andalucía entre 1261 y 1272. Antes de convertirse en almirante mayor de la mar, cargo que asumió en 1260 para sustituir a don Ruy López de Mendoza, don Juan García fue mayordomo de Alfonso X. Sobre este personaje véase R. Sánchez Saus. "El Almirantazgo de Castilla hasta don Alonso Jofré Tenorio: redes de parentesco y tradición familiar”, M. González Jiménez e I. Montes Romero-Camacho (ed.). La Península Ibérica entre el Mediterráneo y el Atlántico. Siglos XIII-XV. Sevilla-Cádiz, 2006, p. 774.

25. C. Torres Delgado. El antiguo reino nazarí de Granada (1232-1340). Granada, 1974, pp. 157-158.

26. M. González Jiménez. "Cortes de Sevilla de 1261”. Historia. Instituciones. Documentos, 25 (1998), pp. 295-311. En adelante, HID.

27. El control de la villa de Jerez resultaba esencial para organizar las campañas de África puesto que esta zona representaba la base territorial necesaria para asaltar las costas de la otra orilla del Estrecho.

28. Todo indica que don Garci Gómez Carrillo era abuelo de don Fernando Díaz Carrillo, fundador de un señorío nobiliario en la cordobesa villa de Santa Eufemia a fines del siglo XIII. Véase sobre esta cuestión E. Cabrera. "Un pionero de la repoblación nobiliaria en los siglos XIII y XIV. Fernando Díaz Carrillo, señor de Santa Eufemia”, VI Estudios de Frontera. Población y poblamiento en la Frontera (homenaje a don Manuel González Jiménez). Jaén, 2006, pp. 156-157. 
documento de la época ${ }^{29}$. Niebla, rendida en marzo de 1262 , fue efectivamente la primera gran conquista de Alfonso X en Andalucía ${ }^{30}$.

En 1263 el monarca castellano "vazió" de moros la villa de Écija ${ }^{31}$. Se trataba de una violación más de los tratados alcanzados con los mudéjares, que vieron cómo durante la primera década del reinado del Rey Sabio su situación jurídica y sus condiciones de vida no hicieron sino deteriorarse imparablemente ${ }^{32}$. Muhammad Ibn al-Ahmar había tomado buena cuenta de lo ocurrido en Niebla y tenía razones fundadas para pensar que la misma suerte podía correr el reino de Granada. A fin de cuentas, dada la forma en que se habían enrarecido las relaciones entre castellanos y musulmanes peninsulares desde la subida al trono de Alfonso X, los granadinos tenían motivos suficientes para temer que en cualquier momento su propio reino se convirtiera en el objetivo militar de Castilla. Así pues, el con-

29. Diplomatario, doc. núm. 262 (p. 292).

30. ¿Por qué Alfonso X se decidió a conquistar Niebla en 1261? En principio, no existía un casus belli que justificara esta agresión: por un lado, en esa fecha los moros de Niebla ya no suponían una amenaza para Sevilla, como probablemente así fuera en 1253; por otro, Ibn Mahfuz había demostrado ser un buen vasallo del rey de Castilla. Francisco García Fitz relaciona la conquista de Niebla con los proyectos ultramarinos de Alfonso X, para los que el rey necesitaba dominar toda la costa atlántica andaluza. De hecho, la Crónica de Alfonso $X$ alude al consejo que pidió el monarca a sus allegados sobre "a quál destas conquistas -Jerez o Niebla-yría primeramente". Véase F. García Fitz. "Alfonso $\mathrm{X}$ y sus relaciones con el Emirato granadino: política y guerra", ob. cit., p. 50.

31. La expulsión de los moros de Écija debió producirse entre 1262 y 1263. ¿Por qué en esa fecha? Manuel González Jiménez sostiene que en esos años debió fallecer el alcayad astigitano Abén Porcoz, cuyo prestigio e influencia fueron enormes tanto en Écija -el texto del repartimiento lo llama "alcayde e sennor de Eçija"- como en toda la comarca. Además, fue él probablemente quien gestionó la capitulación de 1240 y con él, por tanto, habría alcanzado Fernando III el compromiso de respetar la existencia de una comunidad islámica en la villa. Sin embargo, tras su muerte todo cambió: Alfonso $\mathrm{X}$ debió aprovechar la nueva coyuntura para alterar por completo la situación de la almaja mudéjar decretando la expulsión forzosa de la gran mayoría de los moros de Écija. Véase M.J. Sanz Fuentes. "Repartimiento de Écija". HID, 3 (1976), pp. 542-543. Véase asimismo Diplomatario, pp. LIX-LX.

32. El acceso al trono de Alfonso X marca el punto de inflexión de la tolerancia a los pactos mudéjares. El nuevo rey de Castilla antepuso los intereses de la Corona a los compromisos contraídos con los vencidos, de manera que se encargó personalmente de desplazar de sus dominios a los pobladores musulmanes, antes y después de la revuelta mudéjar de 1264. Considerados como un enemigo potencial para las futuras poblaciones cristianas, sus pactos fueron vilipendiados y anulados por la propia Corona mediante la imposición de un férreo sistema fiscal y de marginación socio-cultural, o directamente a través de la expulsión. La historia de las relaciones del rey con las comunidades mudéjares está plagada de gestos de esta índole. En este sentido, la política revisionista de los acuerdos firmados por su padre afectó directamente a los mudéjares de Morón, Cote y Arcos en 1254 y 1255, como ya hemos visto, y a los de Poley (hoy Aguilar de la Frontera), Écija, Osuna, Zambra, Rute y Benamejí, entre otras localidades, en 1262 y 1263 . Antes de 1264 la presencia castellana en la Frontera se había limitado al control militar de las principales fortificaciones mediante la instalación de guarniciones que en realidad venían a representar pequeños islotes de gente armada rodeada por un mar de súbditos mudéjares y, además, muy próximas a un poder islámico política y militarmente organizado como era el reino de Granada, con el consecuente peligro que ello entrañaba; por otra parte, la presencia de mudéjares en Andalucía daba muy mala imagen al reino de un monarca que aspiraba a ser Emperador de Occidente. Estos motivos explicarían que en el proyecto político del nuevo rey de Castilla los mudéjares andaluces, simplemente, no entraran, y ello sería una de las principales causas de la revuelta de 1264 , si no la principal. Véase sobre este asunto M. González Jiménez. "Alfonso X y las minorías confesionales de mudéjares y judíos", M. Rodríguez Llopis (coord.). Alfonso X. Aportaciones de un rey castellano a la construcción de Europa. Murcia, 1997, pp. 71-90. 
vencimiento por parte de los mudéjares andaluces y murcianos de que los pactos firmados con el monarca castellano eran papel mojado, la dramática e injustificada conquista de Niebla y la desconfianza del emir nazarí hacia su señor don Alfonso -que desde su elección como Rey de Romanos en $1257^{33}$ estaba dando muestras de un belicismo exacerbado-, serían los motivos que explicarían el estallido de la famosa revuelta mudéjar de $1264^{34}$.

Hasta la primavera de ese año, Muhammad I no había manifestado indicio alguno de rebelión. Sin embargo, por lo menos desde 1263 estaba consintiendo la presencia en Algeciras y Tarifa de contingentes de "voluntarios de la fe" mariníes $^{35}$, al tiempo que sus emisarios y espías soliviantaban a los mudéjares de Murcia y Andalucía. La ocultación por parte del emir de sus intenciones levantiscas hasta el estallido mismo de la sublevación hizo que el primer sorprendido por los acontecimientos fuese el propio Alfonso $\mathrm{X}^{36}$. El rey había vivido en el convencimiento de que la frontera con Granada no suponía amenaza alguna puesto que el sultán nazarí, vasallo de Castilla desde el pacto suscrito en Jaén en 1246, venía cumpliendo lealmente con sus obligaciones feudales: pagar cada año los tributos acordados (parias), socorrer militarmente a Alfonso X cuando éste demandaba sus servicios (auxilium milites) ${ }^{37}$, sentarse en las Cortes castellanas cada vez que eran convocadas (consilium) $)^{38}$ y acudir a la Corte cuando su presencia era requerida ${ }^{39}$.

Pero, como hemos indicado, en la primavera de 1264 el emir granadino comenzó "la más fuerte guerra que pudiese fazer" 40 y habló "encubiertamentre con los moros que morauan en nuestras uillas et en nuestros castiellos" para que "se

33. Sobre el llamado fecho del Imperio véase M. González Jiménez. Alfonso X el Sabio. Barcelona, 2004, pp. 111-120, 205-208 y 273-290.

34. Muhammad I sabía perfectamente que una sublevación contra Alfonso X suponía la ruptura inmediata del vasallaje y, por tanto, de una tutela que le repugnaba y que se traducía en una permanente sangría económica para las arcas granadinas. Si a ello le añadimos la inseguridad en la que debía vivir el sultán, temeroso de que tarde o temprano podría llegarle la hora a él también, como de hecho le llegó a Ibn Mahfuz, su traición al rey castellano es absolutamente entendible.

35. La crónica benimerín de Ibn Abi Zar da la cifra de 3.000 "voluntarios de la fe". Véase Ibn Abi Zar. Rawd al-Qirtas (traducción y anotaciones de A. Huici Miranda). Valencia, 1964, vol. II, p. 575.

36. Un estudio detallado de la revuelta mudéjar de 1264-1266 puede encontrarse en Diplomatario, pp. LXXI-LXXVIII.

37. En las Cortes de Toledo de 1260, por ejemplo, Muhammad I se comprometió a ayudar a Alfonso X a conquistar el norte de África. Hasta mayo de 1262 el rey no pudo salir de dudas acerca de esta promesa, y, entonces, el sultán granadino le ofreció su apoyo para ocupar Ceuta, plaza que desde hacía algunos años estaba en el punto de mira de Alfonso X como parte de su proyectada cruzada $a$ África.

38. Ya hemos indicado que Muhammad I estuvo presente en las Cortes de Toledo de 1260, convocadas para tratar el fecho del Imperio. A la consulta del monarca castellano a su vasallo nazarí sobre este asunto, el rey de Granada respondió que si no lograba ser aceptado como Emperador que viniese "a esta tierra", que él le ayudaría a conseguir "mayor e meior imperio que aquél" (Diplomatario, p. LXXIII).

39. La última vez que aparece Muhammad I como confirmante de un privilegio alfonsí, señal de haber acudido a la Corte castellana en calidad de vasallo del rey, es en un diploma dado en Sevilla el 28 de junio de 1261: "Don Aboabdille Abén Nazar, rey de Granada, vassallo del rey, conf." (Diplomatario, doc. núm. 246 (pp. 273-275)).

40. Crónica, p. 30. 
alçassen todos con él a día sennalado" $"$. La insurrección debió propagarse por Murcia y Andalucía como un reguero de pólvora: "el rey Alboaquez ${ }^{42}$ et todos los otros moros que auían fincado en el regno de Murçia alçáronse contra el rey don Alfonso e cobraron algunos castillos que tenían los christianos". Sincrónicamente, "los moros que auían fincado en Xerez et en Arcos e en Lebrixa e en Matrera, alçáronse contra el rey don Alfonso, e el rey de Granada començó a fazer la guerra"43.

Iniciado el conflicto, la primera reacción del rey de Castilla fue enviar una carta a don Pedro Lorenzo, obispo de Cuenca, para darle noticia detallada del alzamiento de Muhammad I y pedirle que predicase la bula de cruzada. En esa carta, emitida en Sevilla el 20 de junio de 1264, el monarca expresaba con dolor su pesar por la felonía de un "uassallo e amigo en que fiáuamos"44, confesando que jamás imaginó que "el rey de Granada farie tamanna falsedad e trayción contra nos", sobre todo desde que él mismo se había comprometido a ayudarle a conquistar Ceuta. Fue por medio de embajadores cómo el sultán granadino comunicó al rey castellano que renunciaba al vasallaje, e inmediatamente, sin esperar siquiera que sus emisarios abandonasen Sevilla, "corriónos la tierra et combatiónos los castiellos et matónos los uassallos" "45.

Una vez superados los momentos iniciales de sorpresa, Alfonso X diseñó una estrategia de ataque y defensa: "mandó fazer la guerra contra los moros e enbió poner recabdo en los castillos que estauan fronteros" $"$. Pero en lo que el rey asimiló el levantamiento y empezó a tomar medidas, los musulmanes se hicieron con el control de más de 300 villas y fortalezas ${ }^{47}$. Entre ellas, la Crónica menciona el castillo de Arcos, la torre de Matrera, defendida por un freire calatravo llamado don Alemán y, sobre todo, el alcázar de Jerez, donde la guarnición cristiana fue literalmente pasada a cuchillo: "los moros fueron a la torre que tenía Garcí Gómez et tan afincadamente le conbatieron que quemaron las puertas e mataron los omnes que estauan con él en la torre" ${ }^{" 48}$. Uno de los pocos supervivientes a esa matanza fue precisamente don Garci Gómez Carrillo, vasallo del señor de Lara

41. Diplomatario, doc. núm. 286 (pp. 313-316).

42. Este rey Alboaquez o Alboquez no era otro que Abu Bakr Ben Hud al-Watiq, rey de Murcia desde que en abril de 1264 destronara a Muhammad Ben Abi Yafar, nieto de Muhammad Ibn Hud.

43. Crónica, pp. 30 y 31.

44. Diplomatario, doc. núm. 286 (pp. 313-316). Cinco días más tarde, el monarca escribía a don Andrés, obispo de Sigüenza, para comunicarle también la sublevación de los moros y pedirle asimismo la predicación de la bula de cruzada (Diplomatario, doc. núm. 287 (p. 316)).

45. Diplomatario, doc. núm. 286 (pp. 313-316).

46. Crónica, p. 33.

47. La revuelta mudéjar se inició a mediados de abril de 1264 y todavía a mediados de junio no se había producido la reacción castellana. A lo largo de esos dos meses los musulmanes pudieron hacerse con el control de más de 300 villas y castillos. Véase Jaime I. Llibre dels fets, Barcelona, 1991, caps. 378 y 286, Crónica, p. 39 (nota 42) y Diplomatario, p. LXXII.

48. Crónica, p. 31. Esto mismo debió ocurrir en otras localidades de la zona como Medina Sidonia, Alcalá de los Gazules, Vejer y, tal vez, Lebrija y Sanlúcar de Barrameda. Véase Diplomatario, p. LXXIV. 
y tenente del alcázar jerezano desde 1261, a quien colocaron unos "garfios de fierro" e hicieron cautivo ${ }^{49}$.

Para aplastar la revuelta, los infantes, ricoshombres, caballeros y concejos del reino aconsejaron al monarca "que fuese luego talar la tierra del rey de Granada e quel fiziese el mayor danno que podiese" ${ }^{50}$. Y así se hizo. Desde Alcalá de Abenzaide (hoy Alcalá la Real) Alfonso X "fue por tierra de moros talándoles e quemándoles et faziéndoles mucho mal e mucho danno". Después de la cabalgada, que tuvo lugar en la primavera de 1265 , el rey dio orden a sus súbditos de que permanecieran "en todos los lugares e castillos fronteros faziendo guerra a los moros". Y así fue como, poco a poco, se acabaron recuperando las plazas de Arcos, Matrera, Vejer, Medina Sidonia, Rota, Sanlúcar de Barrameda, Lebrija, Jerez ${ }^{51}$ y cuantas habían caído en poder de los insurrectos ${ }^{52}$. La guerra, no obstante, duró

49. La Crónica de Alfonso X relata que "Garcí Gómez e otros çinco o seys escuderos que estauan con él acogiéronse a la torre mayor del alcáçar e todos los otros christianos fueron muertos. E los moros fueron a la torre que tenía Garci Gómez et tan afincadamente le conbatieron que quemaron las puertas e mataron los omnes que estauan con él en la torre". Don Garci Gómez Carrillo debió ser el único cristiano que sobrevivió al ataque, pues los moros, "non lo queriendo matar por la gran bondat que en él auía", se conformaron con apresarlo y le colocaron unos grilletes (Crónica, p. 31). Otra fuente, en cambio, quizá más objetiva y sin lugar a dudas menos favorable al linaje de los Carrillo, afirma que, tras haberse apoderado los moros del alcázar, "mataron [a] los cristianos, salvo a Gómez Carrillo, que se acogió a una uña de caballo con otros seis, e se fue". La referencia bibliográfica de esta segunda fuente es: G. de la Hinojosa. Estoria del fecho de los godos, Marqués de la Fuensanta del Valle. Colección de Documentos Inéditos para la Historia de España. Madrid, 1893, vol. CVI, p. 13. Sobre este pasaje de la Crónica de Alfonso X véase también M. González Jiménez. "La tenencia de castillos en tiempos de Alfonso X", VI Estudios de Frontera. Población y poblamiento en la Frontera, ob. cit., pp. 297-311.

50. Crónica, p. 34.

51. La villa de Jerez había sido recuperada en el otoño de 1264. Sitiada durante cinco meses -según refiere el cronista- sus defensores, "sintiéndose mucho apremiados de los de la hueste por los muchos males que les fazían con los muchos engennos que les tirauan" y, faltos de víveres, se vieron obligados a solicitar del rey castellano una capitulación que les permitiese al menos "asegurar los cuerpos" (Crónica, p. 38). En este fragmento, la Crónica alude a los "engennos" o ingenios. Debía tratarse de máquinas balísticas o catapultas con las que se arrojaban piedras al enemigo. A veces fallaban, como explica la Primera Crónica General cuando describe la conquista de Alcalá del Río (1247): "se les quebrantauan los engennos a la segunda o a la tercera piedra que tirauan". Pero no debió ser lo habitual. La Crónica de Alfonso $X$ deja entrever la eficacia de estas máquinas de guerra, que eran más requeridas cuanto más fortificada estaba la plaza objeto del asedio. Así, en la conquista de Niebla (1262) el rey ordenó poner "muchos engennos" porque "la villa era muy fortalezida e bien çercada de buen muro e de buenas torres e labradas todas de piedra". También en el cerco de Jerez de 1264 fueron empleadas estas máquinas de guerra: cuando el rey "salió de Sevilla con su hueste et fue çercar la villa de Xerez (...), desque ý llegó, mandó poner muchos engennos en derredor de la villa que tirauan a las torres e al muro e fazían gran danno". Por poner un último ejemplo, en el asedio de Algeciras de 1275 el infante don Pedro, tercer hijo de Alfonso X, y el almirante mayor de la mar "mandaron sacar los engennos e pusiéronlos en aquellos lugares do vieron que cunplía e mandaron que tirasen con ellos a la villa et a los muros de día e de noche e lo más afincadamente que pudiesen". Véase R. Menéndez Pidal (ed.). Primera Crónica General de España, tomo II, ob. cit., pp. 749b-750a, y Crónica, pp. 16, 38 y 198.

52. La gran mayoría de las fortalezas del reino de Sevilla que cayeron en manos mudéjares en el transcurso de la revuelta se situaban en el valle del Guadalete, aunque también hubo algunas ubicadas en la campiña sevillana, como parece el caso de Osuna. Véase M. González Jiménez. "Osuna en el siglo XIII”, J.J. Iglesias Rodríguez y M. García Fernández (coord.). Osuna entre los tiempos medievales 
hasta 1266 porque Muhammad I pudo contar no sólo con un potencial demográfico sorprendente, resultado de la llegada ininterrumpida de mudéjares andaluces y murcianos en años anteriores, sino también con la ayuda de tres mil caballeros zenetes venidos de Marruecos como "combatientes de la fe" ${ }^{53}$. El rey castellano, por su parte, también había jugado sus cartas alentando a los arraeces de Málaga y Guadix, pertenecientes al poderoso linaje de los Ashqilula, a sublevarse contra Muhammad I ${ }^{54}$.

En 1267, tras varios años de enfrentamiento, Ibn al-Ahmar se veía obligado a solicitar del rey castellano unas treguas ${ }^{55}$. En las vistas celebradas en Alcalá de Abenzaide, Muhammad I se comprometió a pagar anualmente 250.000 maravedís en concepto de parias, a dejar de prestar ayuda a los mudéjares murcianos y a dar tregua de un año a los Ashqilula. A cambio de todo ello, Alfonso X se avino a retirar su apoyo a los arraeces sublevados contra el sultán nazarí. Por último,

y modernos (siglos XIII-XVIII). Sevilla, 1995, pp. 39-51. Este texto fue reproducido con pocas alteraciones en M. González Jiménez. La repoblación del Reino de Sevilla en el siglo XIII, ob. cit., pp. 71-87.

53. No sabemos exactamente cuándo cruzaron el Estrecho estas tropas norteafricanas. La Crónica del rey don Alfonso décimo señala que ocurrió en plena revuelta mudéjar: "[Muhammad I] veyendo el gran afincamiento de la guerra en que estaba, envió rogar a Aben Yuzaf que le enviase alguna gente en su ayuda, e enviole mil caballeros e vino por cabdillo dellos un moro que era tuerto de un ojo e decían que era de los más poderosos que habia allen mar". Sin embargo, el propio monarca reconoce en su carta al obispo de Cuenca que el rey de Granada había llamado a contingentes norteafricanos antes ya de que se iniciara la revuelta: "él ouo passado quanto poder pudo de allent mar" sabedor de que "nos estáuamos más assossegado e assegurado e con más poca companna" (Diplomatario, doc. núm. 286 (pp. 313-316)). Por otra parte, Francisco García Fitz ve más verosímil la cifra trescientos jinetes (reseñada por Ibn Idari) que la tradicional de tres mil (como apuntaron Ibn Abi Zar e Ibn Jaldun). Véase F. García Fitz. "Alfonso X, el reino de Granada y los Banu Asqilula. Estrategias políticas de disolución durante la segunda mitad del siglo XIII". Anuario de Estudios Medievales, 27 (1997), pp. 222-223.

54. Los Ashqilula constituían un linaje granadino de origen muladí emparentado con la dinastía nazarí: dos hijos de Alí Ibn Escalluela -amigo personal de Ibn al-Ahmar, a quien había ayudado a convertirse en el primer emir independiente de Granada- casaron con dos hijas del sultán granadino. Sin embargo, en 1257 se inició el distanciamiento entre ambas familias, al vincular Muhammad I el trono a sus hijos Muhammad y Yusuf, en lugar de a sus yernos Abu Ishaq, arráez de Comares, y Abu Muhammad, gobernador de Málaga. Esta decisión echó por tierra las esperanzas de los Ashqilula de convertirse en reyes de Granada. Más tarde, entre 1263 y 1264 Muhammad I se apoyó en los zenetes marroquíes para enfrentarse contra Alfonso X, gesto que tampoco gustó a los Ashqilula, quienes se sintieron desplazados una vez más. La participación en la revuelta mudéjar de los contingentes norteafricanos requería una modificación de la estructura militar granadina en orden al establecimiento de nuevas líneas de mando, que hasta entonces habían estado exclusivamente en manos de los Ashqilula. Los arráeces de Málaga y Guadix intentaron convencer a Muhammad I de que desposeer a los suyos en beneficio de extraños era una torpeza que debía ser reparada, pero sus razonamientos no fueron atendidos. Ahí sería realmente cuando comenzaron las desavenencias entre ambos linajes hasta el punto de que éstos acabaron sublevándose contra el emir en 1266 ó 1267. Alfonso X no perdió entonces la oportunidad de fomentar las querellas internas en el reino de Granada y envió tropas en auxilio de los Ashqilula, que a partir de este momento jugarán un papel destacadísimo en las relaciones entre Castilla y Granada.

55. Según el profesor González Jiménez, Alfonso X y Muhammad I se reunieron en dos ocasiones: 1265 , cuya entrevista no tuvo éxito porque el pacto alcanzado se rompió a poco de firmarse; y 1267, que sí supondría la tregua definitiva. Joseph F. O'Callaghan, en cambio, habla de un único tratado, el de 1267. Sobre esta cuestión véase M. González Jiménez. Alfonso X el Sabio, ob. cit., p. 181, y J.F. O'Callaghan. El Rey Sabio. El reinado de Alfonso X de Castilla (traducción de Manuel González Jiménez). Sevilla, 1996, p. 233. 
Alboaquez, rey de Murcia, falto de la ayuda del granadino y confiado en la promesa hecha por el monarca castellano de respetarle la vida, salió a su encuentro en Santisteban del Puerto y se puso "en la su merçed" flicto, la primera guerra entre Castilla y Granada desde la fundación del sultanato nazarí, cuyas consecuencias serían trascendentales tanto para Murcia como para Andalucía ${ }^{57}$. Como es natural, la primera medida que adoptó el rey castellano fue la represión y, a la postre, la expulsión del valle del Guadalquivir y de Murcia de buena parte de la población islámica, aquélla que no había sido expulsada en años anteriores.

Entre 1266 y 1268 Alfonso X estuvo repoblando la comarca del Guadalete y la bahía de $\mathrm{Cádiz}^{58}$, y entre 1271 y 1272 lo encontramos en el reino de Murcia ${ }^{59}$ "poblando la tierra e faziendo labrar e reparar los castillos" ${ }^{\prime 60}$. Como buen estratega, el Rey Sabio aprovechó los años de calma que le brindaron las paces de Alcalá para reforzar demográficamente los territorios fronteros y reconstruir las murallas y fortalezas andaluzas y murcianas que habían sido dañadas durante la revuelta. ¿Por qué en esos años el rey de Castilla no cesó de preparar a sus reinos meridionales para un posible conflicto armado que se podría avecinar, creando con ello un ambiente prebélico cada vez más acusado? Por una parte, aunque se viviesen tiempos de paz, la guerra siempre estaba de fondo y era necesario estar preparados por si volvía a estallar. Por otra, en 1269 le pudieron llegar noticias de que "el rey de Granada le quería mouer guerra" y, de hecho, "auía començado a fazer mal e danno a los arrayazes que eran en su seruiçio" ${ }^{61}$. Este estado de alerta continua estaba desde luego justificado: a comienzos de la década de 1270 la violencia volvía amenazar al reino. Por un lado, en 1271 se produjo una algarada contra Vejer de la Frontera protagonizada por un ejército de benimerines que había cruzado el Estrecho para apoyar a Muhammad I ${ }^{62}$-lo cual suponía naturalmente la ruptura

56. Crónica, p. 43.

57. De Murcia, en relación a este asunto, Juan Torres Fontes escribió lo siguiente: "la sublevación mudéjar de 1264 supuso un retroceso inesperado a la política alfonsí en Murcia y a sus proyectos de allend mar". Para el caso andaluz, González Jiménez toma el año 1264 como punto de inflexión en la evolución de la sociedad andaluza, de manera que habla de una primera etapa de "implantación de un modelo social característico de una sociedad repobladora en expansión”, fechada entre 1225 y 1264, y un segundo momento de "adaptación del modelo a una situación de frontera", que iría desde 1264 hasta 1310. Efectivamente, el Tratado de 1267 suponía que Granada sería considerada a partir de ahora como un Estado tributario de Castilla, pero no como uno vasallo: a estas alturas era ya imposible restablecer la confianza mutua de antaño. Véase J. Torres Fontes. El concejo de Cartagena en el siglo XIII. Murcia, 1977, p. XXI, y, del mismo autor, La reconquista de Murcia en 1266 por Jaime I. Murcia, 1987. Véase también M. González Jiménez. "De la expansión a la crisis: la sociedad andaluza entre 1225 y 1350 ", F. Toro Ceballos y J. Rodríguez Molina (coord.). Estudios de Frontera. Alcalá la Real y el Arcipreste de Hita. Jaén, 1996, pp. 211-238 (ver aquí p. 212).

58. M. González Jiménez y M.A. Carmona Ruiz. Documentación e itinerario de Alfonso X el Sabio. Sevilla, 2012, pp. 48-59.

59. Ibid., pp. 66-70.

60. Crónica, p. 65.

61. Crónica, p. 52.

62. A finales de 1271, el emir meriní Abu Yusuf recibió un mensajero del sultán granadino "pidiéndole que socorriese a la religión y salvase a los musulmanes andaluces y dándole cuenta de que 
inmediata de las treguas firmadas en $1267^{63}$ - y, por otro, a comienzos de 1272 se inició una sedición contra la Corona castellana encabezada por buena parte de la nobleza que contó para su causa con la ayuda logística y militar de los emires granadinos Muhammad I y Muhammad II. Esta vez, las causas del conflicto hay que buscarlas dentro del propio reino castellano.

En efecto, entre comienzos de 1272 y finales de 1273 tuvo lugar una gravísima revuelta contra la Corona dirigida por el infante don Felipe y don Nuño González de Lara, y secundada por una serie de ricoshombres e hidalgos descontentos con determinados aspectos de la política de Alfonso X. La concepción de una monarquía sólida por parte del Rey Sabio chocaba frontalmente con la idea de ver al monarca como un primus inter pares, a lo que estaban acostumbrados los nobles castellanos. Para ellos, el rey era el caudillo en la guerra y el administrador del reino en tiempos de paz y, sobre todo, el gran dispensador de rentas y beneficios ${ }^{64}$. Esa confrontación ya había provocado en años anteriores tensiones y conflictos entre la nobleza y la Corona ${ }^{65}$, pero no sería hasta 1272 cuando estallara la verdadera sublevación nobiliaria con la que los magnates del reino pretendieron defender, a toda costa, "sus fueros, usos y costumbres" antiguos, gravemente perjudicados por las reformas administrativas, legislativas y fiscales introducidas por Alfonso X.

Después de que el monarca se negase a aceptar algunas de las peticiones que los nobles demandaron en las improvisadas Cortes de Burgos de 1272, éstos "partieron de Canpos e robaron muchas casas syn derecho e syn razón, e pasaron

Alfonso lo habia estrechado en su país" (Ibn Abi Zar. Rawd al-Qirtas, vol. II, ob. cit., p. 585). Sobre esta correría véase Crónica, p. 71 (nota 119).

63. La única explicación posible para entender la ruptura por parte del rey de Granada de las treguas firmadas en Alcalá de Abenzaide en 1267 es que Alfonso X hubiera seguido dispensando un trato de favor al clan familiar de los Ashqilula, arraeces de Málaga, Guadix y Comares. En efecto, cuando se cumplió la tregua de un año establecida entre Muhammad I y los Ashqilula, el rey de Granada se entrevistó con Alfonso X para exigirle que cumpliera la parte que le correspondía en el acuerdo, es decir, el desamparamiento de los sediciosos. Sin embargo, según la Crónica, el rey de Castilla "non quiso desanparar los arrayaces, ante les dixo que los anpararia e defendería porque ouiesen el sennorio sobre sy e que non obedesçiesen al rey de Granada nin a otro ninguno" (Crónica, p. 45).

64. M. González Jiménez. Alfonso X el Sabio, ob. cit., p. 240.

65. En 1255 Alfonso $X$ hubo de hacer frente a su primer problema serio con la nobleza del reino. El origen del conflicto estuvo, probablemente, en el descontento de un sector nobiliario por las reformas legislativas que se estaban haciendo y por el paulatino reforzamiento del poder real. A la cabeza de la sublevación se encontraban don Diego López de Haro, señor de Vizcaya, y el infante don Enrique el Senador, hermano del propio monarca. En octubre de ese año, ambos magnates se levantaron contra la Corona en los territorios extremos del reino, es decir, Vizcaya y Andalucía. E incluso el de Haro se convirtió en vasallo del rey aragonés Jaime I, que acogió con los brazos abiertos a los nobles castellanos "desnaturados". El infante don Enrique, por su parte, llegó a hacerse con el control de la villa de Écija, pero fue desalojado de ella por las tropas reales y derrotado finalmente en los campos de Lebrija. La victoria de Alfonso X sobre estos insurrectos vino a afianzar el proceso de fortalecimiento del poder regio emprendido por el monarca. De alguna manera, la sublevación de 1255 constituye la primera de una larga serie de enfrentamientos entre la monarquía y la nobleza, empeñada en impedir la consolidación de las nuevas ideas políticas del rey que, por otra parte, están en la base de lo que algunos siglos más tarde será el Estado Moderno. Véase sobre este asunto C. González Mínguez. Poder real y poder nobiliar en la Corona de Castilla (1252-1369). Bilbao, 2012. 
Duero para fuyr a tierra de moros" ${ }^{\$ 6}$. Y desde Granada, ciertamente, operaron los nobles sublevados cuyo número se ha calculado en 1.200 caballeros. Desnaturados del rey de Castilla, don Felipe, don Nuño y el resto de ricoshombres rindieron "pleito e omenaje" a Muhammad I y a su hijo y heredero Muhammad II ${ }^{67}$. El emir nazarí se beneficiaba así de una política que tan buenos resultados le había dado al rey de Castilla en años anteriores: la de amparar a los vasallos que se sublevaban contra su señor. La muerte de Muhammad I en enero de 1273 convertía a Muhammad II en rey de Granada y en el nuevo señor de los sublevados. La marcha de los nobles castellanos a Granada suponía inevitablemente el comienzo de otra guerra abierta: Alfonso X, desde Toledo, ordenó al infante don Fernando y a los caballeros de Andalucía "que fiziesen guerra al rey de Granada la más que pudiesen e que ayudasen a los arrayazes"68. A don Fernando, específicamente, le aconsejó que no tuviera desperdigadas las tropas de que disponía en la Frontera y le instó a efectuar una entrada punitiva en la vega de Granada, como aquélla que tan eficazmente había llevado a cabo el propio monarca en $1265^{69}$. El emir de Granada, por su parte, buscó otra vez ayuda en el norte de África y un ejército benimerín cruzó el Estrecho para correr la tierra de los cristianos, matar y cautivar hombres, robar ganado y combatir castillos, como el de Vejer ${ }^{70}$. Tras una serie de operaciones militares -a las que la Crónica se refiere genéricamente como "el fecho de la guerra con los moros"-, y después también de una intensa negociación llevada a efecto vía epistolar, era restablecida la paz en el reino. En lo que al emir nazarí respecta, el pacto de 1273 contenía una serie de cláusulas realmente onerosas: a cambio de no pagar parias durante diez años, Muhammad II debía entregar al rey de Castilla "los puertos de Algezira e de Tarifa"71, devolver "Guadix a los arrayazes", es decir, a los Ashqilula, y convertirse en vasallo de Alfonso X bajo el pago de unas

66. Crónica, p. 92.

67. Crónica, p. 124

68. Crónica, p. 128.

69. La Crónica reproduce una de las cartas que desde Toledo envió Alfonso X al infante don Fernando de la Cerda. Un interesante fragmento de la misma es el que sigue: "tengo que sy vos juntásedes los que están puestos por fronteros en los castillos con ésos que tenedes ý con vusco et con las gentes de pie que podriedes auer en la frontera, e fuésedes agora a la Vega de Granada mientra es el pan verde, e avnque otro mal non les fiziésedes synon en pisándolo, gelo tiraríades; e si ellos aquel poco de pan perdisen, con el otro danno que reçibirían en las huertas e en las vinnas e con el danno que les han fecho los que están en Granada, tengo que muy poco duraría la guerra" (Crónica, p. 149).

70. De la misma forma que los granadinos extendieron políticamente el conflicto al implicar guerreros meriníes, los castellanos hicieron lo propio al solicitar y obtener ayuda militar del rey aragonés Jaime I, que se dirigió a los magnates catalanes para animarles a participar junto al rey de Castilla en la guerra contra Granada. Véase F. García Fitz. “Alfonso X y sus relaciones con el Emirato granadino: política y guerra", ob. cit., p. 63.

71. Hay que entenderlo como un intento de controlar los puertos por donde estaban desembarcando las guarniciones meriníes. En cualquier caso, este punto del acuerdo nunca se cumplió. Tampoco era la primera vez que se incumplía un pacto así: cuando en el lejano mayo de 1262 Muhammad I se entrevistó con el rey de Castilla para proponerle una acción conjunta en la conquista de Ceuta, empresa en la que el emir nazarí había fracasado el año anterior, y Alfonso X le exigió a cambio la entrega de los puertos de Algeciras y Tarifa como base de las operaciones navales, en Granada debieron entender la gravedad del peligro que ello suponía para sus intereses, razón por la cual la Corte nazarí se negó a cumplir la promesa realizada por Ibn al-Ahmar. 
nuevas parias que quedaron fijadas en "trezientas vezes mill marauedis" embargo, lo que más dolió al emir fue que a última hora la reina doña Violante, la verdadera negociadora en este conflicto, solicitase de él que diese tregua por dos años a los arraeces. Sorprendido por esta petición, no prevista ni tratada, no tuvo otra salida que otorgarla ${ }^{73}$. Éste sería, de hecho, el principal motivo por el que Muhammad II pediría auxilio militar al sultán benimerín Abu Yusuf Yacub, el Abén Yuçaf de la Crónica, el Aboyuçef de las Cantigas, quien entre 1275 y 1285 tantos estragos causaría en tierras andaluzas ${ }^{74}$.

Exacto. Los diez últimos años del reinado de Alfonso X estuvieron marcados, entre otros asuntos trascendentales ${ }^{75}$, por la llamada invasión mariní, de la que se ha escrito bastante y es hoy un asunto bien conocido ${ }^{76}$.

72. Crónica, pp. 129 y 169.

73. La reunión de Sevilla había sido una encerrona para el emir: desconocedor por completo de la cláusula de la tregua a los arráeces que la reina le exigiría a última hora, Muhammad II pasó primero por Córdoba para entregar en fieldad al maestre de Calatrava el dinero acordado, nada menos que 1.000.000 de maravedís (450.000 en concepto de las parias de los dos últimos años, 300.000 como adelanto de la próxima anualidad y 250.000 para financiar "la yda al Imperio" de Alfonso X). Una vez liquidada tan alta suma, se dirigió a Sevilla a fin de entrevistarse con la reina doña Violante, en un momento en el que los nobles sublevados ya habían alcanzado un acuerdo con la Corona y, por tanto, no suponían una baza para él. El rey nazarí tuvo así que acceder forzado a conceder la detestable tregua a los arráeces, aunque finalmente consiguió que fuera sólo por un año: "al rey de Granada pésol mucho con este ruego (...) e de su voluntat non lo quisiera fazer, pero por el grant afincamiento de la reyna e del infante ouo de otorgar esta tregua a los arrayazes por vn anno" (Crónica, p. 169).

74. A corto plazo, el engaño urdido en Sevilla parecía resultar rentable para Castilla en sus relaciones con Granada: la rebelión nobiliaria había concluido y Muhammad II se había quedado sin el apoyo de los ricoshombres castellanos, se reanudó el pago de las parias, los arráeces podían estar tranquilos, al menos, durante un año, y la paz volvía a las fronteras del reino. Pero la nueva situación en la que quedaba el emirato nazarí - fragmentado, tributario y acorralado- echaba inevitablemente a Muhammad II a las manos de los benimerines, que no dudaron en auxiliar a su correligionario. En este sentido, la intensa presión a la que fue sometido el sultán de Granada en 1273 y las devastadoras consecuencias que a medio plazo ello tuvo para Castilla, no hicieron sino poner de relieve la poca altura de miras que la reina doña Violante mostró como negociadora y como diplomática en este conflicto. Es más, puede que el propio Alfonso X no estuviera al tanto del desconocimiento que sobre la tregua a los arráeces tenía Muhammad II cuando acudió a Sevilla, lo que explicaría la sorpresa del rey castellano después de que Abu Yusuf cruzara el Estrecho e iniciara un nuevo enfrentamiento armado en Andalucía. Véase F. García Fitz. "Alfonso X y sus relaciones con el Emirato granadino: política y guerra", ob. cit., pp. 68-69.

75. Entre ellos destacan el fecho del Imperio, la crisis sucesoria desencadenada a raíz de la inesperada muerte del infante don Fernando de la Cerda el 25 julio de 1275 y, por supuesto, la guerra civil entre Alfonso X y su hijo el infante don Sancho (1282-1284).

76. El tema de las incursiones mariníes por la Frontera durante el último cuarto del siglo XIII ha sido ampliamente estudiado por don Francisco García Fitz. Una relación básica de su obra sobre este asunto es la que sigue: F. García Fitz. "Los acontecimientos político-militares de la Frontera en el último cuarto del siglo XIII", Revista de Historia Militar, 64 (1988), pp. 9-71; "La frontera castellanogranadina a fines del siglo XIII", C. Segura Graíño (ed.). IV Coloquio de Historia Medieval Andaluza. Relaciones exteriores del Reino de Granada. Almería, 1988, pp. 23-35; Castilla y León frente al Islam. Estrategias de expansión y tácticas militares (siglos XI-XIII), ob. cit.; Relaciones politicas y guerra. La experiencia castellano-leonesa frente al Islam. Siglos XI-XIII. Sevilla, 2002; "La defensa de la frontera del Bajo Guadalquivir ante las invasiones benimerines del siglo XIII", M.J. Viguera Molins (ed.). Las relaciones de la Península Ibérica con el Magreb (siglos XIII-XVI). Madrid, 1988, pp. 275-323; "Una frontera caliente. La guerra en las fronteras castellano-musulmanas (siglos XI-XIII)", C. de Ayala Martínez et al. (ed.). Identidad y representación de la frontera en la España medieval (siglos XI-XIV). 
En la década que va de 1275 a 1285 los benimerines asolaron hasta en cinco ocasiones el valle del Guadalquivir. Dominadores absolutos de todo el Magreb tras derrotar a los almohades ${ }^{77}$, en marzo de 1275 Abu Yusuf equipó a 5.000 jinetes y cruzó con ellos el Estrecho en una veintena de naves ${ }^{78}$. La coyuntura no podía ser más propicia: Alfonso X se encontraba fuera de Castilla $^{79}$ y el resto del reino no estaba preparado para la guerra ${ }^{80}$. El emir de Granada puso a disposición de los benimerines los puertos de Algeciras y Tarifa para el desembarco, y la ciudad de Ronda para la estancia. En mayo de ese año comenzaba la aventura benimerín por tierras de Andalucía: Abu Zayan Mendil, hijo de Abu Yusuf Yacub, "salió hacia Albuhera (Vejer), la saqueó y envió el botín a Algeciras; continuó su marcha por el país enemigo, matando, razziando y destruyendo aldeas y fortalezas, quemando las mieses, talando los árboles frutales y arrasándolo todo, hasta que llegó a Jerez" "1. después, "se encaminó a Algeciras con la presa y los cautivos infieles encadenados". Simultáneamente, Abu Yusuf convocaba las cabilas norteafricanas a la guerra santa ${ }^{82}$ y se dirigía hacia Écija, en cuyos campos tuvo lugar una cruenta batalla.

Efectivamente. La guerra de frontera, al igual que la guerra medieval en general, pocas veces fue un asunto de batallas ${ }^{83}$. Muy al contrario, consistió más bien en saqueos sistemáticos, robos de ganado, quema de cosechas, asalto y destrucción de villas y aldeas, y asedios de fortalezas y ciudades amuralladas ${ }^{84}$. En el comportamiento militar de las sociedades medievales prevaleció siempre, por

Madrid, 2001, pp. 159-179; y, por último, "Estrategias internacionales en el contexto de sociedades de frontera. La amenaza africana en las relaciones castellano-andalusíes, siglos XI al XIII", II Estudios de Frontera. Actividad y vida en la frontera (en memoria de don Claudio Sánchez Albornoz). Jaén, 1998, pp. 269-292. Sobre este tema véase también la obra de M.A. Manzano Rodríguez. La intervención de los benimerines en la Península Ibérica. Madrid, 1992.

77. Para todo lo referente a la conquista y consolidación de los benimerines en Marruecos véase la obra de Ibn Abi Zar. Rawd al-Qirtas (traducción y anotaciones de A. Huici Miranda), vol. II, ob. cit.

78. F. García Fitz. "Los acontecimientos político-militares de la Frontera en el último cuarto del siglo XIII", ob. cit., p. 13.

79. Desde el otoño de 1274 hasta el de 1276 Alfonso X estuvo en varias ciudades de la corona de Aragón, así como en Beaucaire, Montpellier, Narbona y Perpiñán entrevistándose con el Papa Gregorio X y haciendo valer sus derechos al trono imperial. Véase M. González Jiménez y M.A. Carmona Ruiz. Documentación e itinerario de Alfonso X, ob. cit., pp. 75-78.

80. Quizás por ello Alfonso X solicitó ayuda de su cuñado Eduardo I de Inglaterra para hacer frente a los moros (Diplomatario, doc. núm. 423, p. 448).

81. Ibn Abi Zar. Rawd al-Qirtas, vol. II, ob. cit., p. 593.

82. Sobre la noción de yihâd o Guerra Santa y su utilización por parte de los benimerines de Abu Yusuf véase F. García Fitz. "Estrategias internacionales en el contexto de sociedades de frontera. La amenaza africana en las relaciones castellano-andalusíes”, ob. cit., pp. 286-287.

83. F. García Fitz. Las Navas de Tolosa. Barcelona, 2005, pp. 16-17.

84. La posibilidad de movimiento que ofrece el ganado en momentos de peligro hizo que el pastoreo predominara siempre sobre las tareas de tipo agrícola en la frontera. Véase sobre esto M.A. Carmona Ruiz. "La actividad ganadera en la Banda Morisca", M. García Fernández (dir.). La Banda Morisca durante los siglos XIII, XIV y XV. Actas de las II Jornadas de Temas Moronenses. Morón de la Frontera, 1996, pp. 157-173, y especialmente, p. 157. Véase también C. Argente del Castillo Ocaña. "Las actividades agroganaderas en la Frontera", II Estudios de Frontera. Actividad y vida en la frontera, ob. cit., pp. 73-97, y especialmente, p. 89. 
tanto, la expedición de castigo y el cerco a enclaves fortificados sobre cualquier otra forma de agresión, teniendo así los enfrentamientos campales un carácter excepcional. Pero esto no significa que no se libraran batallas ocasionales. Durante el reinado de Alfonso X constatamos en la frontera de Granada, al menos, cuatro, siendo la de Écija la primera de ellas.

La batalla de Écija tuvo lugar el 8 de septiembre de $1275^{85}$. Varios días antes, el alcaide de la fortaleza astigitana, don Nuño González de Lara, "enbió llamar a todos los de la Frontera que viniesen a él a Eçija, porque sopo que Abén Yuçaf venía a correr la tierra de los christianos por aquella parte"\$6. Según la Crónica, el magnate castellano no debía tener muy claro lo de la batalla, y es probable, incluso, que "quisiera ese día escusar la pelea". Sin embargo, llegado el momento, don Nuño y los suyos acudieron al campo de batalla y dio comienzo el enfrentamiento: "don Nunno e los que estauan con él pelearon con los moros que venían con Abén Yuçaf e fueron vençidos los christianos e murió ý don Nunno en la pelea et muchos de los que yuan con él"s7.

Las pérdidas cristianas fueron numerosas y significativas. Entre los nobles que perecieron ese día se encontraban, además del poderoso señor de Lara, don Jufré, alcalde de Écija y sobrino de don Jufré de Loaysa, ayo de la reina doña Violante ${ }^{88}$. Rawd al-Qirtas cifra en 18.000 las bajas cristianas frente a tan solo 24 musulmanas $^{89}$. Se trata, evidentemente, de un balance falseado, pero da una ligera idea del contundente triunfo mariní. La Crónica de Alfonso X, por su parte, se limita a decir en relación al número de caídos que "Abén Yuçaf fue ver qué gentes de los christianos murieron en aquella pelea et fallaron a don Nunno muerto en el canpo e yazían aderredor dél muertos muchos caualleros e quatroçientos escuderos de pie quel guardauan, e otras muchas gentes de christianos"90.

Cuando Abu Yusuf vio el cadáver de don Nuño "mandól cortar la cabeça e enbióla al rey de Granada" "Mul. Muhammad II, al ver los despojos del magnate, "pesó mucho con la muerte de don Nunno, ca éste fizo mucho porque él fuese rey, e esta cabeça enbiólla a Córdoua e envió dezir que la enterrasen con el cuerpo" "92.

85. Miguel Ángel Manzano fecha el enfrentamiento el día 7 de septiembre y no el 8 (M.A. Manzano Rodríguez. La intervención de los benimerines en la Península Ibérica, ob. cit., p. 24).

86. Crónica, p. 178.

87. Crónica, pp. 178-179 y nota 258.

88. M. González Jiménez. "Población y repartimiento de Écija”, Homenaje al Profesor Torres Fontes, vol. I. Murcia, 1987, pp. 691-711. Este estudio fue reproducido en lo esencial y con el mismo título en M. González Jiménez. La repoblación del Reino de Sevilla en el siglo XIII, ob. cit., pp. 13-56 (ver aquí p. 25).

89. Ibn Abi Zar. Rawd al-Qirtas, vol. II, ob. cit., pp. 598-602.

90. Crónica, p. 179.

91. El envío de la cabeza de don Nuño al rey de Granada tenía un claro significado político y simbólico: era un signo del triunfo y del poder meriní y una señal que se enviaba al granadino, antiguo aliado de don Nuño.

92. Crónica, p. 179. Según Ibn Jaldún, Muhammad II cogió la cabeza de don Nuño, "la puso en almizcle y alcanfor y la envió a Alfonso para servirle y atraérselo", hecho que el propio historiador interpreta como una señal del odio que el emir nazarí sentía realmente hacia el sultán mariní. Véase F. García Fitz. "Los acontecimientos político-militares de la Frontera en el último cuarto del siglo XIII", ob. cit., p. 16. 
Además de la recompensa que el sultán meriní debió cobrar de Muhammad II por haber vencido a don Nuño - "tomó su parte de aquella cabalgada", refiere escuetamente el cronista-, Abu Yusuf se retiró a Algeciras con un sustancioso botín que Ibn Abi Zar cuantifica en 124.000 cabezas de ganado vacuno, 14.700 caballos, asnos y mulas, 7.830 cautivos, y un sinfín de adargas, armas y pertrechos ${ }^{93}$.

Mientras Abu Yusuf combatía en los campos de Écija, otro de sus hijos, Abu Yakub, arrasaba con un ejército de retaguardia los alrededores de Almodóvar, Córdoba, Úbeda y Baeza, llegando incluso a conquistar al asalto la fortaleza de Huelma.

Unas semanas más tarde, el emir de Granada se sumaba, según lo acorda$\mathrm{do}^{94}$, a la ofensiva benimerín poniendo en marcha una campaña contra la villa de Martos, encomienda de la orden de Calatrava. Allí se produciría la segunda gran batalla de las cuatro que, como hemos indicado, se libraron en la Frontera de Alfonso X. En esta ocasión, los contendientes fueron las tropas de Muhammad II, de un lado, y las del infante don Sancho de Aragón, arzobispo de Toledo, del otro. El infante don Sancho, hijo de Jaime I y arzobispo primado de España, convocó a la hueste a "todos sus caualleros e los caualleros vasallos del rey que morauan en Toledo e en Talauera e en Guadalajara e en Madrit" y se dirigió con ellos al obispado de Jaén, donde la sede toledana poseía un estratégico señorío conocido como Adelantamiento de Cazorla ${ }^{95}$. Una vez en tierras jiennenses, y a instancias del comendador de Martos, el arzobispo quiso hacer frente al ejército que había atacado el territorio de la jurisdicción calatrava. En un día indeterminado del mes de octubre de 1275 tuvo lugar el enfrentamiento. Segunda batalla y segundo desastre: "los moros tornaron al arçobispo e pelearon con él, et commo los moros eran muchos, fueron vençidos el arçobispo e los que yuan con él, e fue preso el arçobispo e muertos muchos de los christianos" ${ }^{\text {96 }}$. La Crónica es especialmente gráfica en la descripción de este suceso: los vencedores desnudaron al arzobispo "de las armas e de las otras vestiduras que leuaua” y después se desató "muy grant pelea entre si", porque mientras unos querían llevarlo ante Muhammad II, otros preferían entregárselo a Abén Yusuf. Al final, ni una cosa ni otra: un arráez llamado Abén Macar "dio de las espuelas al cauallo e fue al arçobispo do estaua desnuyo e diól con vna azagalla por ençima del onbro que le entró al cuerpo e matólo". La explicación que da el cronista para esta ejecución estriba en la disputa que, sin quererlo, había generado el infante entre las dos facciones surgidas para

93. Ibn Abi Zar. Rawd al-Qirtas, vol. II, ob. cit., pp. 602-603.

94. La Crónica de Alfonso $X$ habla de un acuerdo entre Muhammad II y Abén Yusuf que debió ser alcanzado nada más llegar el sultán norteafricano a la Península: "el acuerdo fue en esta manera: que fuese Abén Yuçaf a correr tierra del regno de Seuilla e que començase por Éçija, e que el rey de Granada que fuese a fazer guerra por el obispado de Jahén" (Crónica, p. 177).

95. Sobre el Adelantamiento de Cazorla véase M.M. García Guzmán. El Adelantamiento de Cazorla en la Baja Edad Media. Un señorío eclesiástico en la frontera castellana. Cádiz, 1985. Véase también, de la misma autora, Colección Diplomática del Adelantamiento de Cazorla (1231-1495). Cádiz, 1991. Y véase, finalmente, M. González Jiménez. En torno a los orígenes de Andalucía. La repoblación del siglo XIII. Sevilla, 1988, pp. 32 y 38.

96. Crónica, p. 182. 
decidir precisamente sobre su propio destino: "non quiera Alá que por vn perro se maten tantos buenos commo aquí están" 97 , dijo Abén Macar.

Cuando don Lope Díaz de Haro, señor de Vizcaya, llegó allí con su mesnada "acogiéronse a él muchos de los que escaparon de la pelea que venían fuyendo". A la mañana siguiente, "desque fue el día esclaresçido, don Lope Díaz fue al lugar do mataron al arçobispo et troxo el cuerpo dél syn cabeça e syn la mano". Para recuperar los miembros amputados del prelado "enbió demandar a los moros la cabeça e la mano del arçobispo e diérongelo e leuáronlo con el cuerpo a Toledo a enterrar"98.

Por tanto, entre mayo y noviembre de 1275 tuvo lugar la primera invasión benimerín de Andalucía: entre mayo y julio Abu Zayan Mendil devastó las tierras de Vejer y Jerez; entre agosto y septiembre Abu Yusuf asoló los campos de Écija y su hijo Abu Yakub los de Almodóvar, Córdoba y el Alto Guadalquivir; y entre octubre y noviembre las tropas de Muhammad II corrieron la tierra de Martos.

Mientras tanto, en Castilla el desbarajuste era total: tras la muerte de don Nuño González de Lara, adelantado de la Frontera ${ }^{99}$, y de don Sancho de Aragón, arzobispo de Toledo, no quedaba en Andalucía ningún cargo importante que asumiese la defensa de toda la frontera. Don Fernando de la Cerda, infante heredero y regente durante la ausencia del rey, que se encontraba en el Imperio, se dirigió desde Burgos a tierras andaluzas para unificar las fuerzas disponibles y atacar frontalmente a granadinos y benimerines. Pero cuando conoció la noticia de que tanto don Nuño como su tío el arzobispo habían perecido, se detuvo en Villa Real (hoy Ciudad Real) "a esperar los de los regnos que avía enbiado llamar". Para colmo de desdichas, "estando el infante don Ferrando en aquella villa, adolesçió de grant dolençia et veyéndose quexado de la muerte fabló con don Juan Núnnez" y luego "este infante don Ferrando finó en el mes de agosto" 100 . A partir de este momento entra en escena el infante don Sancho quien desde Córdoba, y por iniciativa propia, se puso al frente de la defensa de Andalucía ${ }^{101}$.

97. Ibid.

98. Crónica, p. 183.

99. Durante el reinado de Alfonso X se sucedieron, con toda seguridad, un total de cuatro Adelantados en la Frontera: Pedro Ruiz de Olea (enero-junio de 1253), Sancho Martínez de Jódar (junio de 1253-abril de 1258), Diego Sánchez de Funes (junio de 1258-enero de 1261 y junio de 1272-marzo de 1273) y Alfonso García de Villamayor (marzo de 1261-enero de 1272); y, probablemente, dos más si consideramos titulares del cargo al señor de Lara y al de Molina: Nuño González de Lara (¿1274-septiembre de 1275?) y Alfonso Fernández "El Niño" (¿1274-1281?). Sobre esta cuestión véase los siguientes trabajos de B. Vázquez Campos: "Sobre el origen del cargo de Adelantado de la Frontera", Sevilla, 1248. Congreso Internacional Conmemorativo del 750 Aniversario de la Conquista de la Ciudad de Sevilla por Fernando III, Rey de Castilla y León, ob. cit., pp. 813-820; "Sobre los orígenes del Adelantamiento de Andalucía", HID, 27 (2000), pp. 333-373; "Frontera y adelantamientos en época de Alfonso X”, HID, 30 (2003), pp. 513-535; Los adelantados mayores de la Frontera o Andalucía (siglos XIII-XIV). Sevilla, 2006; y Adelantados y lucha por el poder en el reino de Murcia. Alcalá la Real (Jaén), 2009.

100. Crónica, p. 184.

101. Para ello contó con el auxilio de las órdenes militares. Su difunto hermano don Fernando había preferido actuar con sus propios medios, posiblemente alertado por el consejo que le dio su padre acerca de los maestres de las órdenes, en quienes había perdido la confianza ya en 1273: "cuídate de 
En el momento en que Alfonso X "sopo cómmo pasara Abén Yuçaf aquende la mar con grandes poderes de gentes e que los moros mataron al arçobispo don Sancho et a don Nunno, et otrosí sopo de cómmo era muerto el infante don Ferrando", pensó, y con razón, que "la Frontera era en condiçión de se perder toda o la mayor parte della". Por ese motivo "partió de Belcayre e vénose para Castilla" "102. En diciembre de 1275 el monarca se encontraba ya de vuelta en Alcalá de San Juste (hoy Alcalá de Henares). El hecho de que no se hubieran perdido territorios en Andalucía "plógole mucho al rey", pero la delicada situación en la que se encontraba el reino requería la firma de una tregua con Abu Yusuf y con el rey de Granada. Esta tregua también beneficiaba al sultán mariní quien, a decir del cronista, "plógol della, ca la flota de los christianos que auía enbiado don Sancho a la guarda de la mar non le dexava venir vianda", por lo que "las gentes que tenía

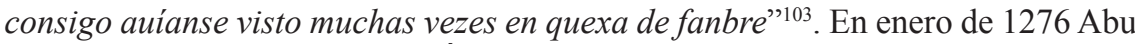
Yusuf y los suyos regresaron a África.

La segunda intervención benimerín en la Península Ibérica se desarrolló entre agosto de 1277 y junio de 1278. En enero del primer año, Abu Yusuf Yacub, el rey de Marruecos como le intitula la Crónica, escribió desde Rabat a las cabilas del Magreb convocándolas para la guerra santa. Durante el mes de junio se realizó el desembarco de las tropas en la playa de Tarifa y el 1 de julio arribó la nave del emir. Pero esta vez no hubo una petición de ayuda por parte del rey nazarí, por lo que ahora los granadinos no constituirían una fuerza auxiliar. Tampoco importaba: el éxito rotundo de las campañas de 1275 debía ser aval más que suficiente para confiar plenamente en sus capacidades militares. Ahora bien, ¿cómo sentó a Muhammad II el desembarco, sin previo aviso, de un ejército mariní en Tarifa, que a fin de cuentas seguía siendo una plaza del reino de Granada? El profesor García Fitz apunta, en este sentido, que el emir nazarí debió ver en los benimerines el mismo peligro que constituía Alfonso X porque el propio Abu Yusuf podía haber pensado en la posibilidad de desbancar a Muhammad II del trono andalusí: "el precedente almohade no estaba tan lejano", sentencia el medievalista ${ }^{104}$.

Desde Tarifa, el sultán benimerín viajó a Algeciras y de allí a Ronda, donde se entrevistó con los señores de Guadix y Málaga. A comienzos del mes de agosto, su ejército partió de Ronda y acampó en las proximidades de Sevilla, y al día siguiente, tras pasar la noche en Itálica, tomó al asalto las villas de Guillena y Cantillana.

la maestría del maestre de Vclés" llegó a decirle en una ocasión. Sin embargo, el infante don Sancho, ajeno por completo a estas circunstancias, se apoyó en las órdenes militares durante la ausencia del rey, hasta el punto de que el Papa Gregorio X comunicó a los legados de la Sede Apostólica, y concretamente a los colectores de la décima con destino al subsidio de Tierra Santa, que los maestres y freires de Calatrava, Alcántara y Avis quedaban exentos del pago de dicha décima por los servicios prestados en defensa de la fe cristiana cuando en mayo de 1275 los sarracenos norteafricanos desembarcaron en Tarifa. Véase sobre este asunto C. de Ayala Martínez. "Las órdenes militares castellano-leonesas y la acción de frontera en el siglo XIII", Identidad y representación de la frontera en la España medieval (siglos XI-XIV), ob. cit., p. 138.

102. Crónica, p. 188.

103. Crónica, p. 189.

104. F. García Fitz. "Los acontecimientos político-militares de la Frontera en el último cuarto del siglo XIII”, ob. cit., p. 19. 
No sabemos lo que ocurrió después porque las fuentes musulmanas se contradicen: según Rawd al-Qirtas, Abu Yusuf, después de tomar sendas villas "espada en mano", se dirigió al enclave de Alcolea del Río y luego al Aljarafe, que fue arrasado; sin embargo, si seguimos la crónica Risala I, el sultán abandonó Cantillana para dirigirse a Lora del Río y Constantina, donde murieron 400 cristianos, y a Morón de la Frontera, cuyo arrabal fue devastado ${ }^{105}$. A finales de agosto, Abu Yusuf regresó a Algeciras con un sustancioso botín y dio descanso a las tropas.

No había transcurrido ni un mes cuando Abu Yakub dirigió otra campaña por tierras del Bajo Guadalquivir, concretamente contra los términos de Santa María del Puerto, Rota y Sanlúcar de Barrameda, llegando casi a las puertas de Sevilla. Arrasada la comarca de Jerez y el sur de la tierra hispalense, Abu Yusuf se puso al frente de un ejército que asoló los campos de Córdoba, Porcuna, Arjona y Jaén, por ese orden. En esta correría acabó participando también Muhammad II, cuyas tropas se unieron a las del sultán mariní en Archidona, a medio camino entre Ronda y Granada.

Según Ibn Abi Zar, después de que el rey de Castilla fuera informado de los nuevos estragos causados por los benimerines en tierras andaluzas, "envió sacerdotes y religiosos al emir de los musulmanes para pedirle el perdón y la paz"106. No sabemos si esto ocurrió así exactamente, pero una cosa es cierta: en febrero de 1278 se firmaba una nueva tregua y en junio de ese año Abu Yusuf retornaba al Magreb.

Estaba claro que Alfonso X necesitaba acabar con ese trasiego incesante de benimerines de África a Europa a través del Estrecho. Para poner fin a esta situación, el monarca "fabló con los que eran ý con él que era su voluntat de enbiar çercar la çibdat de Algezira por la tomar a Abén Yuçaf que non pudiese pasar por allí otra vez aquende la mar". Las intenciones del rey cristiano eran evidentes: conquistar por la fuerza la plaza de Algeciras, por la que desde 1275 estaban entrando sistemáticamente tropas norteafricanas. Y con ese propósito ordenó armar en Sevilla una "muy grant flota" que habría de estar compuesta por ochenta galeras y veinticuatro naves con el avituallamiento y armamento necesarios, así como "muchos enjennos para los enbiar en las naues" 107 .

Los nazaríes, por su parte, también tenían motivos para desear el fin de la presencia benimerín en tierras andalusíes. La admiración que Abu Yusuf despertaba en algunos clanes granadinos -como el de los Ashqilula, que en 1277 le cedieron la plaza de Málaga-y, sobre todo, la intervención mariní en la Península ese mismo año sin petición previa, aumentaron el recelo de Muhammad II. Así las cosas, castellanos y nazaríes establecieron una alianza contra el poder norteafricano.

En agosto de 1278, una vez que Abu Yusuf se había instalado en Marruecos, Alfonso X rompió la tregua firmada con él y la escuadra castellana puso cerco a

105. Ibn Abi Zar. Rawd al-Qirtas, vol. II, ob. cit., pp. 609-612. La información del texto Risala I la hemos obtenido de M.A. Manzano Rodríguez. La intervención de los benimerines en la Península Ibérica, ob. cit., pp. 41-42.

106. Ibn Abi Zar. Rawd al-Qirtas, vol. II, ob. cit., p. 616.

107. Crónica, pp. 195-196. 
Algeciras. Mientras la flota bloqueaba el Estrecho, un ejército al mando del infante don Pedro combatía la plaza por tierra, pues en el real se había corrido el rumor de que "los de la villa estauan muy desmayados", de manera que "si fuesen conbatidos, que los christianos entrarían la çibdat". Sin embargo, la campaña no produjo el efecto deseado y "porque ouo muchos feridos de los de parte de fuera, dexaron el conbatimiento". Don Pedro tuvo que conformarse tan solo con "guardar que non entrase en la villa vianda ninguna" ${ }^{108}$. Mientras tanto, Alfonso X y el infante don Sancho hacían gestiones con el rey Pedro III de Aragón.

Junio de 1279 es una fecha decisiva en este conflicto. Por un lado, los granadinos rompieron la alianza alcanzada con Alfonso X tras recuperar la ciudad de Málaga ${ }^{109}$ y conocer el estado de inanición en que se encontraban sus correligionarios algecireños, y, por otro, Abu Yusuf se propuso liberar definitivamente Algeciras del cerco cristiano. A comienzos del verano de ese año, el sultán benimerín ordenaba a su hijo Abu Yakub que armase navíos en Ceuta, Salé y Tánger, desde donde partió una flota que arribó Gibraltar el 19 de julio. Comenzaba la tercera intervención benimerín en Andalucía, que se prolongaría hasta junio de 1281. En cualquier caso, el principal problema de Alfonso X en esos momentos no era que Muhammad II le hubiera retirado su ayuda; ni siquiera que el emir Abu Yusuf acabara de cruzar el Estrecho. El problema más importante del rey de Castilla era que su hijo el infante don Sancho había desviado (para su propio beneficio) el dinero recaudado para el mantenimiento de la hueste y la flota que cercaban Algeciras ${ }^{110}$. Por esta razón, Alfonso X sólo pudo enviar desde Sevilla el dinero que le prestaron algunos mercaderes, lo cual resultaba a todas luces insuficiente. Los miembros de la armada sufrieron las consecuencias de la falta de emolumentos: "los omnes de la flota adolesçieron de muy grandes dolençias, ca muchos dellos, estando en las galeas e non auiendo las viandas, cayéronles los dientes et ouieron otras muchas dolençias" 111.

Ésa fue la situación que se encontró la flota musulmana cuando el 21 de julio de 1279 se enfrentó a la castellana en una sangrienta batalla naval, la tercera en el reinado de Alfonso X. El resultado final de la misma fue la destrucción de la marina cristiana y el levantamiento del cerco de Algeciras: "el rey Abén Yuçaf mandó

108. Crónica, p. 198.

109. Málaga, en manos de los Ashqilula desde 1266, había sido puesta por éstos a disposición de los benimerines en 1277 . Ahora, en 1279, la plaza volvía al poder nazarí.

110. La reina doña Violante, partidaria en un primer momento de que fueran sus nietos don Alfonso y don Fernando -hijos de don Fernando de la Cerda- los herederos al trono de Castilla, huyó con ellos a Aragón, donde fue recibida por su hermano Pedro III. Tras una estancia de más de un año en la Corona aragonesa, en 1279 doña Violante regresó a Castilla cargada de deudas y habiendo dejado en manos de Pedro III a los infantes de la Cerda. Don Sancho de Castilla, para ganarse el apoyo de su madre, pagó a los acreedores de ésta con el dinero que don Zag de la Maleha había recaudado en el reino para el ejército que por entonces sitiaba Algeciras. Dadas sus buenas relaciones con su tío el aragonés, es probable que el infante don Sancho hubiera tenido algo que ver en la decisión de dejar a los infantes de la Cerda en el castillo de Játiva, pues de esta forma alejaba del reino a sus rivales más directos en la sucesión al trono castellano. Sobre el conflicto sucesorio véase M. González Jiménez. Alfonso X el Sabio, ob. cit., pp. 306-308 y 324-327.

111. Crónica, p. 201. 
que todas las gentes de la mar entrasen luego en las galeas et puso ý muchos caualleros de los mejores que él tenía et muy bien armados". Esos caballeros "llegaron a las otras galeas de los christianos et (...) quemáronlas todas e mataron los que estauan en ellas". Una vez aniquilada la flota y su tripulación, "los caualleros moros que yuan en las diez galeas desçendieron a tierra e llegaron aquel lugar do poblaron después la Villa Nueua e mataron ý muchos de los que yazían dolientes" 112 . Tras la victoria benimerín en el sitio de Algeciras, Abu Yakub cruzó el Estrecho pero, en lugar de dirigirse contra los cristianos, decidió hacerlo contra los granadinos por el auxilio que éstos habían prestado a don Alfonso. Mientras tanto, su hermano Abu Zayan Mendil iniciaba el cerco de Marbella.

La amenaza permanente que suponía el poder benimerín en la zona del Estrecho y el Bajo Guadalquivir obligó, por otra parte, al rey de Castilla a reforzar la defensa de la frontera en su sector más débil, es decir, en las tierras de Medina Sidonia y Alcalá de los Gazules; con esa intención concedió ambas villas a la Orden Militar de Santa María de España en diciembre de $1279^{113}$. Poco duraría, no obstante, esta situación porque tras la malograda batalla de Moclín (1280) la Orden marinera, que había sido fundada por el propio Rey Sabio, acabó desapareciendo.

En mayo de 1280 el rey se instaló en Córdoba -convertida a partir de entonces en el centro de operaciones contra Granada-, y en el mes de junio el infante don Sancho reunió en Alcalá de Abenzaide el ejército de su padre y el suyo propio. Desde allí, y a petición del arráez de Guadix, cruzó la frontera y llegó hasta Moclín. Según la Crónica, cuando las tropas cristianas llegaron a "vn castillo de moros que dizen Moclín, que es a dos leguas de Alcalá", se encontraron con una pequeña hueste musulmana formada por apenas cien caballeros que, al ver al potentísimo ejército cristiano, optó por huir. Don Gonzalo Ruiz Girón, maestre de Santiago, la persiguió "con muy poca gente", pero los huidos "leuáronle a vna çelada en que estauan dos mill caualleros de moros" y, "desque fue descubierta la çelada, cogieron en pos dellos e diéronle feridas a este Gonçalo Ruyz de que murió después". La emboscada resultó fatal para el ejército cristiano pues los moros "mataron ý ese día entre caualleros e omnes de pie dos mill et ochoçientos, e muryeron ý todos los más de los freyres de la Orden de Santiago ${ }^{114}$, et catiuaron caualleros e otros muchos omnes" 115 . La imprudencia de don Gonzalo Ruiz no sólo le costó la vida sino que comportó también la desaparición de la Orden de Santa María de España, también llamada de la Estrella ${ }^{116}$. A pesar de la contun-

112. Crónica, pp. 202-203.

113. Diplomatario, doc. núm. 451 (pp. 475-476).

114. Carlos de Ayala sostiene que en esa batalla perecieron 55 freires de la milicia del maestre santiaguista, "la casi totalidad de los que disponía". Véase sobre esto C. de Ayala Martínez. "Las órdenes militares castellano-leonesas y la acción de frontera en el siglo XIII”, ob. cit., p. 141.

115. Crónica, p. 208.

116. La cuantiosa pérdida de la institución santiaguista indujo a Alfonso X a tomar una medida que seguramente le supondría un gran sacrificio personal: extinguir la Orden marinera que él mismo había fundado y reforzar la Orden de Santiago, de tan gloriosa tradición guerrera. Su maestre, don Pedro Núñez, pasó a serlo de la Orden de Santiago y los caballeros de Santa María de España cubrieron las bajas sufridas por los santiaguistas en Moclín. La fusión de ambas órdenes tuvo lugar a finales de 
dente derrota, el infante don Sancho salió con su ejército tres días después "para la Vega et llegó çerca de Granada quemando los panes e talando e derribando quanto fallaua, e desque toda la Vega ouieron talada, tornóse el infante don Sancho con toda la hueste para Jahén". Después regresó a Córdoba para entrevistarse con su padre "et al rey plógol mucho de cómmo el infante don Sancho guiara bien la hueste" "117. En el verano del año siguiente, el infante volvía a invadir el territorio granadino, talando sus árboles frutales y quemando sus mieses. Sin embargo, el viejo problema sucesorio resurgiría de nuevo, transformado esta vez en una auténtica guerra civil que pronto se convertiría también en un conflicto internacional, como veremos enseguida.

La ejecución de don Zag de la Maleha, almojarife real, por parte de Alfonso X en el otoño de 1280 disgustó mucho al infante don Sancho. El motivo de este ajusticiamiento fue que el judío había puesto a disposición del infante el dinero recaudado en Castilla para abastecer a la flota que tenía cercada Algeciras. El caso es que a partir de ese momento, don Sancho "fincó en grant querella del rey por esta muerte deste judio" "118, y ahí precisamente arrancaría un conflicto que entre 1282 y 1284 sumió al reino en una dramática guerra civil ${ }^{119}$. En lo que a las fuerzas musulmanas atañe, Alfonso X consiguió tempranamente el favor del emir benimerín Abu Yusuf con quien firmó una alianza en 1282 gracias a la mediación de don Alonso Pérez de Guzmán ${ }^{120}$. ¿Por qué motivo Abu Yusuf estaba dispuesto a ayudar a su anterior enemigo, el rey de Castilla? Ibn Jaldún atribuye esta alianza a que " $e l$ sultán se apresuró a dar su consentimiento con la esperanza de poder tornar en su propia ventaja la desunión que reinaba entre los cristianos". Pero, en segundo lugar, Abu Yusuf tenía una cuenta pendiente con el rey de Granada: desde comienzos de 1279 éste había tomado posesión de la ciudad de Málaga y, pese a los ímprobos esfuerzos benimerines, el sultán marroquí todavía no se había adueñado de ella. Se presentaba una buena ocasión para intentar de nuevo la conquista de la plaza y así fue cómo dio comienzo la cuarta intervención benimerín en tierras béticas.

abril de 1281. Véase sobre este asunto J. Torres Fontes. "La Orden de Santa María de España", Miscelánea Medieval Murciana, 1977, vol. 3, p. 95. Véase también M. González Jiménez. "Relaciones de las Órdenes Militares Castellanas con la Corona", HID, 18 (1991), pp. 220-221, y, del mismo autor, "Andalucía, Granada y el Estrecho de Gibraltar en tiempos de Alfonso X", Actas del II Congreso Internacional "El Estrecho de Gibraltar". Madrid, 1995, vol. III, pp. 1-25.

117. Crónica, p. 209.

118. Crónica, p. 210.

119. En el fondo del conflicto estaba la indecisión de Alfonso X sobre la herencia del reino, pues existían dos firmes candidatos: don Alfonso de la Cerda, primogénito del difunto heredero don Fernando, y don Sancho, segundo hijo del rey. El infante don Sancho echó en cara a su padre esta indecisión y justificó su legítimo derecho a heredar la Corona aduciendo motivos divinos: "Sennor non me fezistes vos, mas fizome Dios et fizo mucho por me fazer, ca mató a vn mi hermano que era mayor que yo e era vuestro heredero destos regnos si él biuiera más que vos; e non lo mató por ál synon porque lo heredase yo después de vuestros días" (Crónica, p. 219). Sobre la guerra civil entre Alfonso X y el infante don Sancho véase M. González Jiménez. Alfonso X el Sabio, ob. cit., pp. 349-352.

120. En recompensa por su hábil gestión en este negocio, don Alonso Pérez de Guzmán recibió del rey la tenencia de Alcalá de los Gazules (1282), además de su matrimonio con doña María Alonso Coronel. Véase sobre esta cuestión M.A. Ladero Quesada. Los señores de Andalucía. Investigaciones sobre nobles y señoríos en los siglos XIII a XV. Cádiz, 1998, p. 422. 
También al Rey Sabio le interesaba una coalición con los benimerines en relación a su enfrentamiento con Granada. Alfonso X no había olvidado todos los agravios acumulados desde 1264, incluyendo la petición de ayuda a los norteafricanos en 1274 y los destrozos ocasionados en el valle del Guadalquivir durante la guerra de 1275 y 1277 . A todo ello venía a sumarse la destrucción de su flota en 1279, de la que, en parte, era también responsable la traición de Muhammad II $^{121}$.

En el verano de 1282 Alfonso X y Abu Yusuf marcharon juntos desde Écija hasta Córdoba, donde se encontraba el infante don Sancho, y mantuvieron cercada la ciudad durante veintiún días ${ }^{122}$. Desde la antigua capital omeya, Abu Yusuf “envió columnas a Jaén, asoló las cosechas y, luego, marchó a tierras de Toledo, matando, cautivando, robando ganados y destruyendo aldeas y castillos; así llegó hasta Madrid, en tierras de Toledo"123. Después el sultán se retiró a Algeciras. Era noviembre de 1282.

El infante don Sancho, por su parte, ante la alianza de su padre con el emir benimerín, buscó el apoyo de Muhammad II, a quien entregó en contraprestación el castillo de Arenas, en la frontera occidental del reino, que había sido conquistado por el propio Alfonso X. En abril de 1283 Abu Yusuf volvía a la carga con el respaldo de tropas alfonsíes, dirigiéndose en esta ocasión hacia Granada y conquistando las plazas de Cártama, Coín y Fuengirola. Posteriormente puso cerco a la ciudad de Málaga. El duro asedio al que estuvo sometida la plaza obligó al rey de Granada a solicitar de Abu Yusuf una tregua que negoció Abu Yakub: en el mes de junio de 1283 el hijo del sultán meriní conseguía la reconciliación entre ambos mandatarios. Tras el nuevo viraje diplomático, en julio los benimerines llegaron a Córdoba y Baeza y se internaron en Castilla para alcanzar Talavera, ciudad que sitiaron. A su regreso, Abu Yusuf saqueó el obispado de Jaén y en noviembre de 1283 pasó al Magreb.

En enero de 1284 Alfonso X redactaba su segundo testamento y en abril de ese año fallecía en el alcázar de Sevilla. Acababa todo para él, también la guerra civil y sus enfrentamientos contra los musulmanes, los que durante más de veinte años habían marcado su reinado.

121. Para librar la guerra contra su hijo, Alfonso X buscó apoyo en cortes europeas (Francia, Inglaterra, Roma) y peninsulares (Aragón, Portugal), apoyo que todas le negaron. Sin embargo, nunca acudió a la Corte nazarí. Este gesto por parte del monarca pone de manifiesto hasta qué punto las relaciones entre el rey de Castilla y el emir de Granada estaban en 1282 completamente deterioradas. Véase F. García Fitz. "Alfonso X y sus relaciones con el Emirato granadino: política y guerra”, ob. cit., pp. 74-75.

122. A comienzos del verano de 1282 la autoridad de Alfonso X sólo era reconocida explícitamente en el reino de Sevilla y en algunas partes del reino de Murcia, con su capital al frente.

123. Ibn Abi Zar. Rawd al-Qirtas, vol. II, ob. cit., p. 636. Hacía muchas décadas que aquellas tierras no veían a un ejército musulmán algareando por sus inmediaciones, por lo que esta situación debió provocar gran desconcierto y pavor entre sus pobladores. 


\section{El tIEMPO DE LA PAZ. LAS TREGUAS}

Si dejamos a un lado la dura política antimudéjar practicada por Alfonso X y sus continuos enfrentamientos contra almohades, nazaríes y benimerines, podemos verificar que también hubo episodios de buenas relaciones entre el Rey Sabio y el Islam. A la hora de analizar dichas relaciones hemos de valorar principalmente tres aspectos, claves para entender la paz en la frontera: el vasallaje, la tregua y la alianza.

Comenzando por el primero, es bien sabido que Alfonso X fue señor de algunos príncipes y reyezuelos musulmanes. Entre 1252 y 1264 actuó como señor de Muhammad I, rey de Granada ${ }^{124}$, y al menos desde 1253 hasta 1261 lo fue de Ibn Mahfuz, rey de Niebla ${ }^{125}$. También ejerció como señor del rey de Murcia desde 1253 hasta el fatídico año de $1264^{126}$.

Como vasallos suyos, estos mandatarios confirmaron los documentos más solemnes de la cancillería alfonsí y acudieron periódicamente a la Corte y a las Cortes castellanas. Así, cuando en 1254 fueron convocadas Cortes en Toledo -por citar sólo uno de los muchos ejemplos posibles-, "el rey de Granada, por aver la voluntad e amistat del rey don Alfonso más de quanto la auía, veno a él a Toledo, et al rey plógole mucho con su venida e fizol mucha onra" ${ }^{127}$. Durante los primeros años de reinado de don Alfonso, Muhammad I envió incluso a Sevilla una comitiva cada año para rendir homenaje a Fernando III en el aniversario de su muerte ${ }^{128}$. Los mudéjares andaluces tenían desde luego motivos para llorar la muerte del Rey Santo y los príncipes andalusíes, sus vasallos, para lamentar la pérdida de su señor natural, al que siempre respetaron por mutua fidelidad personal ${ }^{129}$.

124. Alfonso X ratificó en dos ocasiones el Pacto de Jaén que firmaran su padre y el primer emir independiente de Granada en 1246: una, nada más subir al trono, a mediados de 1252, y la otra en 1254. La Crónica del Rey Sabio recoge tal ratificación en los siguientes términos: "Et este rey don Alfonso en el comienço de su reynado firmó por tienpo çierto las posturas e avenençias que el rey don Fernando su padre avía puesto con el rey de Granada e que le diesen las parias" (Crónica, p. 5). Desde entonces y al menos hasta 1261 Muhammad I aparece como vasallo de Alfonso X en los diplomas más solemnes de la cancillería castellana: "Don Aboabdille Abén Nazar, rey de Granada, vassallo del rey, conf.". Véase D.M. Pérez Castañera. Enemigos seculares. Guerra y treguas entre Castilla y Granada (1246-1481). Madrid, 2013, p. 141.

125. Entre 1253 y 1261 Ibn Mahfuz confirmó los privilegios rodados de Alfonso X en calidad de vasallo suyo: "Don Abén Mahfot, rey de Niebla, uassallo del rey, conf.".

126. La primera vez que Ibn Hud aparece confirmando diplomas de Alfonso X como vasallo del rey es en un documento fechado el 28 de febrero de 1253: "Don Mahomat Abén Mahomat Abenhut, rey de Murçia, vasallo del rey, la conf." (Diplomatario, doc. núm. 12 (pp. 11-12)).

127. Crónica, p. 10.

128. Narra la Crónica que "Abén Alhmar, rey de Granada, enbiaua al rey don Alfonso para esta onra quando la fazía grandes omnes de su casa et con ellos çient peones que trayan cada uno dellos un çirio ardiendo de çera blanca, et estos çirios poníanlos en derredor de la sepultura do yazía enterrado el rey don Ferrando" (Crónica, p. 27).

129. M. García Fernández. "Alfonso X y la invención de la frontera de Granada (1252-1267)", E. González Ferrín (coord.). Encrucijada de culturas: Alfonso X y su tiempo (homenaje a Francisco Márquez Villanueva). Sevilla, 2014, p. 260. 
Además del vasallaje propiamente dicho, sabemos que Alfonso X ejerció hasta la década de 1260 algún tipo de control sobre los arraeces de ciertas villas murcianas y andaluzas, como la propia Murcia, Lorca o Jerez de la Frontera. Se trataba de un sistema de protectorado mediante el cual el rey de Castilla mantuvo a los caudillos andalusíes en sus respectivas fortalezas a cambio de sumisión, respeto y una cuantía dineraria de la que apenas tenemos información ${ }^{130}$.

Es cierto que cuando las razones de Estado lo exigían, era preciso hacer la guerra. Pero aún siendo así, hasta el propio enfrentamiento podía redundar posteriormente en el establecimiento de buenas relaciones entre los contendientes. Así lo manifestaba, al menos, Alfonso X en las Partidas: "el guerrear, maguer ha en si manera de destruyr e de meter departimiento e enemistad entre los omes (...), quando es fecha como deue, aduze después paz, de que viene assosegamiento e folgura e amistad"'131. Y en todo caso, en el transcurso de un conflicto, si las circunstancias eran adversas y la balanza se equilibraba del lado enemigo, siempre cabía la posibilidad de solicitar treguas del adversario: "el rey de Granada, veyéndose en afincamiento de la guerra con los christianos et otrosy veyendo el mal e el danno que le fazían en la tierra los arrayazes que eran contra él, enbió sus mandaderos al rey don Alfonso con quien le enbió dezir que touiese por bien de le dar tregua"132. La tregua no constituía en sí misma un tratado de paz, pero suponía el cese temporal de las hostilidades ${ }^{133}$. Del reinado de don Alfonso destaca especialmente un pacto de esta índole. Nos referimos al rubricado en Alcalá de Abenzaide en 1267, al que alude el fragmento arriba reproducido. La firma del tratado de Alcalá suavizó las diferencias entre Muhammad I y Alfonso X después de la revuelta mudéjar de 1264. Estos acuerdos solían comportar, no obstante, una serie de cláusulas poco o nada deseables para quienes los solicitaban. En las vistas de Alcalá, por ejemplo, se habló de paz a cambio del pago de un tributo anual de 250.000 maravedís y de ayuda militar para la recuperación del reino de Murcia. Otras treguas significativas fueron las alcanzadas con el sultán beréber Abu Yusuf

130. Un testimonio cronístico contemporáneo, la Crónica Anónima de Sahagún, se refiere en un capítulo a ciertos embajadores de Jerez que acudían a Sevilla para pagar al rey el "tributo acostumbrado". El texto completo de este pasaje dice así: "los moros que estauan allí de Xerez e de los otros castillos que auían traído al rey muchos dones por el tributo acostumbrado, como le biesen ansi llebar en las andas, mucho se a el condoliendo alçauan las manos al çielo". Al hacer alusión a los moros "de los otros castillos", el cronista se está refiriendo, seguramente, a los de aquellos enclaves que por esa fecha pagaban el mismo tributo al rey de Castilla, es decir, Lebrija, Arcos, Cádiz, Medina Sidonia, Alcalá de los Gazules y Vejer de la Frontera, y, por extensión, a los de todas las alquerías pertenecientes a estos municipios, como Alcanate (El Puerto de Santa María), Sanlúcar de Barrameda, Trebujena o Rota. Véase J. Puyol. "Crónicas Anónimas de Sahagún”, Boletín de la Real Academia de la Historia, LXXVII, 1920, p. 174. La misma noticia la recoge Ibn Idari en Al-Bayan Al-Mugrib, A. Huici Miranda (edición y traducción). Colección de Crónicas Árabes de la Reconquista. Tetuán, 1954, vol. III, pp. 29-30.

131. Partida II, título XXIII, ley VII.

132. Crónica, p. 41.

133. C. Argente del Castillo Ocaña. "Las relaciones de convivencia a través de los tratados de paz”, III Estudios de Frontera. Convivencia, defensa y comunicación en la frontera (homenaje a don Juan de Mata Carriazo). Jaén, 2000, pp. 81-102, y especialmente, pp. 83-84. 
Yacub en 1275 y 1278, es decir, tras la primera y la segunda invasión norteafricana, respectivamente ${ }^{134}$.

En la frontera del siglo XIII también fueron frecuentes los sistemas de alianzas entre moros y cristianos ${ }^{135}$. Recuérdese que el infante don Felipe, don Nuño González de Lara y el resto de nobles sublevados en 1272 se convirtieron en vasallos de Muhammad I y de su hijo. Recuérdese también que los arraeces de Málaga, Guadix y Comares fueron "anparados" por Alfonso X, quien llegó incluso a respetar al clan familiar de los Ashqilula ciertas tenencias fronterizas ubicadas en el reino de Jaén ${ }^{136}$. El mismo rey don Alfonso se alió en 1278 con el emir nazarí Muhammad II para hacer frente al poder norteafricano, y en 1282 hizo lo propio con el sultán benimerín Abu Yusuf para afrontar la guerra que durante dos años libró contra su propio hijo el infante don Sancho, quien, por otro lado, buscó el apoyo del rey de Granada.

No hay que olvidar, en cualquier caso, que estas alianzas tenían siempre fines políticos y estratégicos, y que con ellas se perseguían también intereses personales. Alfonso X apoyó a los Ashqilula para debilitar el poder del rey de Granada, idéntico motivo por el que éste amparó a los nobles castellanos sublevados en 1272: fragmentar la unidad de la fuerza adversaria. Es lo que el profesor García Fitz llama la estrategia de disolución ${ }^{137}$. Y, al igual que los enemigos de otros tiempos se podían convertir, según fuera conveniente, en aliados ocasionales, podía ocurrir también que la desconfianza a una posible traición del aliado, llevara a una de las partes a buscar ayuda en una tercera fuerza. Es lo que ocurrió en 1273 cuando el arráez de Málaga, que disfrutaba de la confianza de Alfonso X, envió legados al emir benimerín Abu Yusuf Yacub para ofrecerle su sumisión. Diplomáticamente hablando, hay que reconocer que se trataba de un movimiento inteligente, puesto que sin renunciar formalmente a la protección castellana, los Ashqilula habían conseguido reforzar su posición tanto frente a los nazaríes como a los posibles desamparos del rey de Castilla.

A un nivel más popular, el monarca castellano contó con la ayuda de "moros viejos e sabidores de la tierra" para efectuar los deslindes de términos de las villas conquistadas. Es más, en febrero de 1262, desde el cerco de Niebla y al objeto de establecer el amojonamiento entre los términos de Tiñosa y los de otras localidades cordobesas para resolver la contienda que existía entre la Iglesia de Córdoba

134. Según el profesor Rodríguez Molina, la tregua de 1275 vino seguida de la firma de otra por dos años en 1276, que no nos consta. Véase J. Rodríguez Molina. La vida de moros y cristianos en la frontera. Alcalá la Real, 2007, pp. 103-104.

135. F. García Fitz. "Estrategias internacionales en el contexto de sociedades de frontera. La amenaza africana en las relaciones castellano-andalusíes, siglos XI al XIII”, ob. cit., p. 270.

136. Cuando el 25 de junio de 1275, desde Beaucaire, Alfonso X concedió al concejo de Úbeda los castillos de Tíscar, Huesa y Belerda, en el documento de la concesión especificó que esta última plaza estaba todavía en posesión de "Mahomad, fijo de Handón". El tal Mahomad Ibn Abdún era un miembro del clan de los Ashqilula que hasta la fecha indicada fue señor de una pequeña fortaleza fronteriza del reino de Jaén. Véase a este respecto Diplomatario, doc. núm. 421 (pp. 446-447).

137. F. García Fitz. "Alfonso X, el reino de Granada y los Banu Asqilula. Estrategias políticas de disolución durante la segunda mitad del siglo XIII”, ob. cit., p 219. 
y la Orden de Calatrava, el rey de Castilla no dudó en solicitar la ayuda de "moros de tierra del rey de Granada" que conocieran bien la zona. Atendiendo amablemente a este requerimiento, el emir nazarí envió a diez moros comarcanos cuyos testimonios fueron fundamentales para solventar aquella cuestión ${ }^{138}$. Alfonso $X$ buscó asimismo en los musulmanes los amplios conocimientos que éstos tenían en determinadas áreas científicas y culturales ${ }^{139}$. Así, por ejemplo, en agosto de 1260 el Rey Sabio solicitó del arzobispo y cabildo de la catedral de Sevilla algunas de las mezquitas que les había concedido para poner en ellas la "morada de los físicos que vinieron de allende, e para tenerlos más cerca, e que en ellas fagan la su enseñanza a los que les avemos mandado que nos los enseñen con el su gran saber, ca para eso los avemos ende traído" ${ }^{140}$. Se refiere a los físicos o médicos moros a los que adjudicó la mezquita llamada de los Ossos.

Las Cantigas de Santa María reflejan también la opinión que al monarca y sus súbditos merecían los musulmanes. En términos generales, puede decirse que estaban mejor considerados que los judíos, ya que éstos, como se afirma en la cantiga 348, eran "muy peyores ca mouros". Más aún, a diferencia de los judíos y los beréberes, que las miniaturas de las Cantigas retratan con rasgos marcadamente caricaturescos, los mudéjares aparecen retratados siempre con una gran dignidad $^{141}$. Además, los musulmanes no estaban obligados -como los judíos-a residir en aljamas o barrios apartados, lo cual se comprueba perfectamente en Jerez, donde las veinticinco familias de moros asentadas en 1266 fueron distribuidas por cinco de las seis collaciones de la villa ${ }^{142}$. Incluso puede que el rey pretendiera la conversión de los mudéjares al Cristianismo utilizando para ello la predicación en lugar de la fuerza: "por buenas palabras e conuenibles predicaciones deuen

138. Diplomatario, doc. núm. 253 (pp. 280-281).

139. El monarca fomentó personalmente y de forma muy intensa la labor de traducción de obras árabes de astronomía, astrología, matemáticas, agricultura, filosofía, literatura, religión o historia, de manera que la llamada Escuela de Traductores de Toledo alcanzó, bajo su patrocinio y amparo, uno de sus momentos culminantes. Ahora bien, no debemos perder de vista que, respecto al papel de los sabios musulmanes en la Corte alfonsí, entre sus colaboradores y traductores aparecen judíos, cristianos y un converso del Islam -Bernardo el Arábigo-, pero no hay constancia de ningún personaje musulmán. Además, para Francisco García Fitz y José Manuel Rodríguez García, la producción científica y cultural de Alfonso X no fue sino la expresión ideológica de sus ambiciones políticas, con lo cual, el fenómeno de las traducciones de obras árabes al castellano no sería sino un instrumento más al servicio de las mismas, $\mathrm{y}$, consecuentemente, estarían ajenas por completo a un supuesto filoislamismo intelectual por parte del Rey Sabio. En esta línea, el interés del monarca por fomentar la traducción de obras escritas en lengua árabe no debe entenderse sólo como un mero avance de la cultura, sino como un intento de conocer mejor al enemigo antes de enfrentarse a él. Véase F. García Fitz. "El Islam visto por Alfonso X", Cristianos y musulmanes en la Península Ibérica: la guerra, la frontera y la convivencia. XI Congreso de Estudios Medievales (2007). León, 2009, pp. 400 y 402, y J.M. Rodríguez García. La cruzada en tiempos de Alfonso X. Madrid, 2014, p. 186.

140. Diplomatario, doc. núm. 232 (p. 255).

141. M. González Jiménez. "Alfonso X y las minorías confesionales de mudéjares y judíos”, ob. cit., p. 84 .

142. M. González Jiménez. "Jerez de la Frontera en el siglo XIII", Actas de las II Jornadas de Historia de Jerez. Jerez medieval. Jerez de la Frontera, 1990, pp. 11-19. Este trabajo fue reeditado con el título "Jerez de la Frontera antes y después de la revuelta mudéjar de 1264" en M. González Jiménez. La repoblación del Reino de Sevilla en el siglo XIII, ob. cit., pp. 219-240 (ver aquí p. 235). 
trabajar los christianos de conuertir a los moros, para fazerles creer la nuestra fe e aduzirlos a ella, e non por fuerza nin por premia"143.

En cualquier caso, abrazasen o no la Fe en Cristo, los mudéjares andaluces y murcianos gozaron durante algún tiempo del amparo del rey de Castilla: "como quier que los moros non tengan buena ley: pero mientra biuieren entre los christianos en segurança dellos non les deuen tomar nin robar lo suyo por fuerça", recogen las Partidas ${ }^{144}$.

Con similares términos se dirigía Alfonso X, en junio de 1260, al concejo de Alicante: "bien sabedes uos de como los moros que son en todos nuestros regnos que son nuestros et que los auemos de guardar et de amparar" 145 . Y no sólo habló de protección y amparo, sino también de consideración y respeto a los privilegios y costumbres musulmanas. Así, cuando en 1256 concedió a la orden militar de Calatrava la villa y castillo de Matrera, lo hizo con la condición de sus freires "tengan a los moros que oy son hy moradores, e a los que serán de aquí adelante por sienpre jamás, e tanbién a los de la villa cuemo a los de las aldeas, en todos sus fueros, e en todos sus derechos, en todas cosas"146. Esta disposición obligaba, por consiguiente, a los caballeros calatravos a respetar los privilegios que los mudéjares de Matrera disfrutaban desde los tiempos del rey don Fernando.

Alfonso X, como rey sabio que era, potenció también el conocimiento de las lenguas y, entre ellas, de la lengua árabe. En este sentido, fundó en Sevilla en 1254 un Estudio General de latino y arábigo para que "los maestros e los escolares que uinieren hy al estudio (...) estudien e uiuan en paz en la ciptad de Seuilla"147.

143. Partida VII, título XXIV, ley II. En el siglo XIII asistimos a lo que algunos autores han llamado el "sueño de la conversión”. Sin embargo, la pregunta crucial seguía siendo: ¿era mejor la conversión pacífica mediante la misión predicadora o el enfrentamiento armado para eliminar la presencia de musulmanes en la Península? A pesar de que, al principio, ambas posiciones parecían incompatibles, la conclusión a la que llegaron muchos a finales del siglo XIII -Ramón Llull entre ellos-era que la cruzada debía entenderse como un camino previo necesario para favorecer la predicación y la conversión de los islamitas al Cristianismo. ¿Qué idea tenía Alfonso X a este respecto? La historiografía tradicional siempre ha defendido el esplendor que alcanzó "la España de las tres culturas" durante el reinado del Rey Sabio, un periodo caracterizado supuestamente por la tolerancia religiosa y la convivencia pacífica entre moros y cristianos. En cambio, investigaciones más recientes han puesto en entredicho esa concepción y vienen a apoyar la tesis de Julio Valdeón, quien ya en 1985 defendía que el reinado de Alfonso X no fue tan pacífico como tradicionalmente se ha creído y que el único objetivo del monarca era borrar lo musulmán del territorio andalusí a través de la guerra. En todo caso, hay una verdad evidente: durante el reinado del Rey Sabio no se desarrollaron campañas masivas de predicación y conversión destinadas a los súbditos musulmanes. Véase J.M. Rodríguez García. La cruzada en tiempos de Alfonso X, ob. cit., pp. 176, 177, 186 y 187, y J. Valdeón Baruque. “Alfonso X y la convivencia cristiano-judía-islámica". Estudios Alfonsies. Lexicografía, lírica, estética y política de Alfonso X el Sabio. Granada, 1985, pp. 167-177.

144. Partida VII, título XXV, ley I.

145. J. Torres Fontes. Fueros y Privilegios de Alfonso X, Colección de Documentos para la Historia del Reino de Murcia. Murcia, 1973, vol. III, doc. LV, pp. 74-75.

146. Diplomatario, doc. núm. 179 (pp. 198-200).

147. Diplomatario, doc. núm. 142 (pp. 152-154). Sobre este aspecto véase también M. González Jiménez. "Orígenes medievales de la Universidad de Sevilla", R.M. Serrera Contreras y R. Sánchez Mantero (coord.). V Centenario. La Universidad de Sevilla (1505-2005). Sevilla, 2005, pp. 1-17, y especialmente, pp. 2-9. 
Cabe suponer que algunos de los enseñantes que tomó bajo su protección serían musulmanes.

Las poblaciones de frontera fueron, en definitiva y sin lugar a dudas, testigos directos de contactos violentos entre cristianos y musulmanes, pero fueron, al mismo tiempo, el escenario de frecuentes relaciones comerciales y pacíficas entre vecinos fronteros. Aquella franja separaba dos Estados, pero también dos sociedades, dos religiones, dos lenguas y dos culturas que se influyeron mutuamente, y se enriquecieron gracias a la asimilación de las variopintas $\mathrm{y}$, a veces, exóticas costumbres "del otro". Era una franja que separaba y que, no obstante, también acercaba.

Y si hubo en la frontera gentes que hicieron de la guerra su forma de vida, también hubo quien vivió del contacto pacífico con el contrario. Nos referimos a los alfaqueques y trujamanes, es decir, esos personajes bifrontes que redimían cautivos y liberaban a esclavos y prisioneros de guerra a ambos lados de la raya ${ }^{148}$. Es cierto que las fuentes del siglo XIII no hablan mucho acerca de ellos, lo cual puede deberse a que se trataba de oficios en estado aún embrionario ${ }^{149}$, pero algunas referencias sí que hay: en el repartimiento de Écija, por ejemplo, fue heredado un "alfaqueque" en la villa ${ }^{150}$, y en la Crónica de Alfonso $X$ aparecen un tal " $A b$ dalhat, trujamán" y "Abdalhaque el trujamán"151. A veces, los textos no aluden específicamente a estas profesiones pero sí a la intención por parte de personas anónimas de rescatar a cautivos. Es lo que ocurrió, por ejemplo, con Juan Martínez de San Román, un vecino de Sevilla a quien los moros de Ronda prendieron con dos compañeros mientras segaban los campos de Alcalá de Guadaíra. Llevados a

148. El fenómeno del cautiverio, algo bastante habitual en la Edad Media, se remonta en la Frontera al mismo siglo XIII. Los cautivos podían ser tanto moros como cristianos y, en ambos casos, padecían situaciones absolutamente precarias, derivadas no ya sólo de la pérdida de libertad, sino del trato recibido al ser considerados - como ocurría con los esclavos- "cosas" en lugar de personas. Esta realidad la expresa muy bien un documento de 1280 en el que el maestre de la Orden de Santa María de España se dirige a las autoridades del obispado de Jaén para recordarles que el rey le había concedido ciertos derechos sobre las cosas vedadas y, entre éstos, el de "las cosas mostrencas, así moros como moras, cavallos, roçines, yeguas, mulas, mulos e qualesquier otros ganados e averes perdidos sobre tierra". Véase sobre este asunto C. Argente del Castillo Ocaña. "Los cautivos en la frontera entre Jaén y Granada", IV Coloquio de Historia Medieval Andaluza. Relaciones exteriores del Reino de Granada, ob. cit., pp. 211-225.

149. El alfaqueque es un antiguo oficio fronterizo que aparece regulado ya en Las Partidas, aunque no alcanzó pleno desarrollo hasta los siglos XIV y XV. El ejercicio fundamental de esta profesión era el canje y rescate de cautivos cristianos, por lo que el éxito de sus operaciones dependía en buena medida de la firma de treguas en la Frontera. Los alfaqueques debían ser personas expertas y conocedoras de la lengua árabe y de las costumbres granadinas, y ello les llevó a vestir como musulmanes, e incluso a dejarse la barba. La versión islámica del alfaqueque cristiano era el trujamán. Véase sobre este asunto M. García Fernández. "En la frontera de Granada. La paz y la guerra en la campiña sevillana (siglos XIII-XV)", La campiña sevillana y la frontera de Granada (siglos XIII-XV). Estudios sobre poblaciones de la Banda Morisca. Sevilla, 2005, p. 74. Véase también, del mismo autor, "Sobre la alteridad en la frontera de Granada. Una aproximación al análisis de la guerra y la paz (siglos XIII-XV)". Revista da Facultade de Letras HISTÓRIA. Porto, 2005, III Série, vol. 6, pp. 213-235, y especialmente, p. 231.

150. M.J. Sanz Fuentes. "Repartimiento de Écija", ob. cit., p. 539.

151. Crónica, pp. 75 y 252. 
Morón, "los christianos de la villa quisieron conprar estos captiuos, et non ge los quisieron vender", narra uno de los Miráculos del monje silense Pedro Marín ${ }^{152}$.

\section{VALORACIONES FINALES}

\subsection{Cuantificación de los tiempos de la guerra y la paz}

Decía don Juan de Mata Carriazo que "en la frontera de Granada, la paz y la guerra no eran esas cosas rotundas de siempre y de todas partes: ni la paz era paz, ni la guerra era guerra, en el pleno sentido de cada concepto". Y proseguía: "las más violentas acciones en un sector determinado, se hacían compatibles con relaciones pacíficas y aún benévolas en otros sectores de la frontera”. Pero hecha esta aclaración preliminar, el historiador continuaba su discurso exponiendo sólidos argumentos que le hacían concluir que el ambiente general en la frontera de Granada fue violento, ya que ni siquiera los periodos de paces y treguas eran estables y seguros: "las treguas no eran tales treguas: todo lo más, un estado de guerra atenuada" 153 .

Últimamente ha venido desarrollándose una corriente historiográfica revisionista empeñada en defender sólo la primera parte de la tesis de Carriazo, es decir, en demostrar que en la frontera de Granada predominó siempre la convivencia pacífica sobre la violencia y la guerra. En esa corriente sobresale, entre otros, el profesor José Rodríguez Molina, para quien la frontera fue "un espacio permeable y de prolongados intercambios, que supera con mucho al de las guerras o cabalgadas y a las pretendidas incursiones sin cuento". De esto se deduce que "la sociedad de Frontera, en general, aspira a vivir en paz, lo intenta y lo consigue con frecuencia y durante prolongados periodos”. Y, en esta línea, Rodríguez Molina defiende, con todas las reservas que se quiera ${ }^{154}$, que hubo dos tiempos en la frontera: "el

152. Los milagros de Pedro Marín se escalonan entre 1274 y 1287, años que parecen enmarcar la actividad de este monje benedictino como cronista minucioso de los milagros de Santo Domingo de Silos. Véase M. González Jiménez. "Esclavos andaluces en el Reino de Granada", Actas del III Coloquio de Historia Medieval Andaluza. La sociedad medieval andaluza: grupos no privilegiados. Jaén, 1984, pp. 327-338, y especialmente, pp. 329 y 332.

153. J.M. Carriazo y Arroquia. En la frontera de Granada. Sevilla, 1971, p. 140.

154. El autor reconoce lo atrevido que puede resultar hablar de un predominio significativo de paces y treguas frente a la guerra y la violencia en la frontera castellano-granadina: "Abordar el tema de la convivencia entre cristianos y musulmanes en la España de la Edad Media puede parecer un intento temerario". Con estas palabras inicia el medievalista un artículo dedicado a la convivencia entre cristianos y musulmanes en la frontera de Granada. Más adelante, vuelve a insistir en lo difícil que resulta para el historiador analizar la historia a contra corriente: "uno se siente, sinceramente, cohibido ante tan interesantes y rigurosos trabajos como se han elaborado recientemente, dejando rotundamente sentadas en numerosas y documentadas páginas la intolerancia entre cristianos y musulmanes o la violencia generalizada". Y, sin embargo, concluye su discurso afirmando que "mi quehacer historiográfico y el contacto con la documentación generada día a día en las poblaciones asentadas en el sector fronterizo, me hace captar una realidad social con matices y enfoques divergentes de esa monolítica y rotunda interpretación tradicional" (J. Rodríguez Molina. "Convivencia de cristianos y 
tiempo de paz y tregua, no tan breve y peligroso, como se ha pretendido en ciertos ámbitos, y el tiempo de la guerra, reducido a periodos no tan prolongados ni traumáticos como suelen relatar las crónicas, romances y cartas de frontera" 155 .

Desde hace años, el análisis efectuado por este reputado medievalista ha abarcado, es cierto, todo el periodo bajomedieval y no un reinado o una centuria concreta. Además, él ha focalizado sus estudios en el Alto Guadalquivir y sólo en contadas ocasiones se ha referido a las fronteras cordobesa y sevillana. Siendo así, no podemos cuestionar que, efectivamente, entre los siglos XIII y XV la frontera del reino de Jaén viviera, en su conjunto, prolongados periodos de paz frente a momentos puntuales de guerra.

Sin embargo, y pese a esta aparente acotación inicial del espacio investigado, en trabajos más recientes el profesor Rodríguez Molina ha ido más allá y se ha atrevido a cuantificar la duración del "tiempo de la paz" y del "tiempo de la guerra" para toda la frontera del siglo XIV, traspasando, por tanto, las fronteras del marco geográfico al que suele dedicar sus estudios, y restringiendo también la cronología en la que normalmente se mueve. Así, en 1996 escribió: "Durante el siglo XIV, podríamos encontrarnos con la sugerente sorpresa de una duración de las treguas y paces próxima a los 85 años, mientras que las guerras se distribuirían en un conjunto de 15 años, repartidos a lo largo de toda la centuria"156. Estos datos, deducidos de la lectura atenta de actas capitulares y cartas fronterizas acabaron siendo extrapolados por él mismo a toda la raya bajomedieval cuando, generalizando su discurso, aseveró que "existe la necesidad de abordar el estudio de la Frontera a través de dos tiempos, el tiempo de la guerra, no tan prolongado como se ha creído, que oscilaría en torno al 15\%, mientras que el tiempo de la convivencia, presidido por las paces y treguas, con un $85 \%$ del total, sería el más acostumbrado y, desafortunadamente, el peor o nulamente descrito"157.

¿Fue esto realmente así? Puede que sí, no lo vamos a discutir. Puede que entre 1237 y 1492 predominaran los periodos de paz sobre los espacios de guerra en aquella línea larga y compleja que iba "desde Lorca a Tarifa". Puede incluso que los tiempos de paz superasen en el sector frontero del reino de Jaén ese $85 \%$ que propone el profesor Rodríguez Molina. Ahora bien, llegados a este punto cabría plantearse dos cuestiones: ¿sucedió lo mismo en el Bajo Guadalquivir a lo largo de todo el periodo bajomedieval? Y, sobre todo, ¿son estos datos aplicables de alguna manera a la frontera de Alfonso X? Evidentemente, no.

En los apartados anteriores hemos descrito y datado los periodos de guerra $\mathrm{y}$ paz vividos en tiempos de Alfonso X. Constatamos que de 32 años de reinado, la

musulmanes en la frontera de Granada", La Paz en la Historia. Granada, 2000, pp. 189-228, y especialmente, pp. 189 y 192-193).

155. J. Rodríguez Molina. La vida de moros y cristianos en la frontera, ob. cit., pp. 102-103.

156. J. Rodríguez Molina. "La frontera de Granada, siglos XIII-XV", Estudios de Frontera. Alcalá la Real y el Arcipreste de Hita, ob. cit., p. 508.

157. J. Rodríguez Molina. "Convivencia de cristianos y musulmanes en la frontera de Granada", ob. cit., p. 195. Esta misma hipótesis la podemos encontrar en su trabajo "Relaciones pacíficas en la frontera con el Reino de Granada", Actas del Congreso La Frontera Oriental Nazarí como sujeto histórico (siglos XIII-XVI). Almería, 1997, pp. 257-290 (ver aquí p. 259). 
guerra estuvo presente en 22, mientras que la paz sólo en 10. Observemos ahora el siguiente cuadro:

Tabla: Cuadro cronológico de la guerra de frontera en el reinado de Alfonso X

\begin{tabular}{|c|c|c|}
\hline $\begin{array}{l}\text { Año de } \\
\text { reinado }\end{array}$ & Hecho bélico & $\begin{array}{c}\text { Duración de } \\
\text { hecho }\end{array}$ \\
\hline 1252 & - & \\
\hline 1253 & Conquista de Tejada y campaña contra Jerez & $?$ \\
\hline 1254 & Expulsión de los mudéjares de Morón & $?$ \\
\hline 1255 & Expulsión de los mudéjares de Arcos & $?$ \\
\hline 1256 & - & \\
\hline 1257 & Conquista de Tagunt & $?$ \\
\hline 1258 & - & \\
\hline 1259 & - & \\
\hline 1260 & Conquista de Salé & $?$ \\
\hline 1261 & Conquista definitiva de Jerez y cerco de Niebla & 6 meses \\
\hline 1262 & Cerco y conquista de Niebla & 3 meses \\
\hline 1263 & Expulsión de los mudéjares de Écija & $?$ \\
\hline 1264 & Revuelta mudéjar & 9 meses \\
\hline 1265 & Revuelta mudéjar y saqueo de la vega de Granada & 12 meses \\
\hline 1266 & Revuelta mudéjar & ¿12 meses? \\
\hline 1267 & - & \\
\hline 1268 & - & \\
\hline 1269 & - & \\
\hline 1270 & - & \\
\hline 1271 & Algara benimerín contra Vejer & $?$ \\
\hline 1272 & Sublevación nobiliaria con el apoyo de Muhammad I & 12 meses \\
\hline 1273 & Sublevación nobiliaria con el apoyo de Muhammad II & 12 meses \\
\hline 1274 & - & \\
\hline 1275 & Primera invasión benimerín & 7 meses \\
\hline 1276 & - & \\
\hline 1277 & Segunda invasión benimerín & 5 meses \\
\hline 1278 & Segunda invasión benimerín & 6 meses \\
\hline 1279 & Tercera invasión benimerín & 6 meses \\
\hline 1280 & Tercera invasión benimerín & 12 meses \\
\hline 1281 & Tercera invasión benimerín & 6 meses \\
\hline 1282 & Cuarta invasión benimerín & 6 meses \\
\hline 1283 & Cuarta invasión benimerín & 11 meses \\
\hline 1284 & - & \\
\hline
\end{tabular}


Salta a la vista que durante el reinado de don Alfonso hubo un predominio claro de la guerra sobre la paz. Resulta muy difícil cuantificar estas realidades, como de hecho ha efectuado Rodríguez Molina, pero un cálculo aproximado podría ser el siguiente. Si partimos de que Alfonso X reinó durante 382 meses exactamente, y consideramos que los acontecimientos bélicos cuya duración desconocemos se prolongaron a lo largo de un mes, el menor de los coeficientes posibles, una sencilla operación matemática nos daría como resultado que el 35\% del reinado de Alfonso X estuvo ocupado por la guerra directa contra los musulmanes. Este porcentaje resulta de la regla de tres aplicada a los 132 meses en los que hubo enfrentamientos casi a diario. Ahora bien, si consideramos que cada año de "hecho bélico" fue un año de guerra, como así debió ser, esa cifra se dispara hasta el 70\%, de manera que podemos concluir diciendo, con razones de peso, que durante el reinado de Alfonso X, en la frontera de Granada, las dos terceras partes del tiempo se dedicaron a la guerra, y la tercera parte restante a otros asuntos en los que, de una manera u otra, la amenaza islámica también estuvo presente.

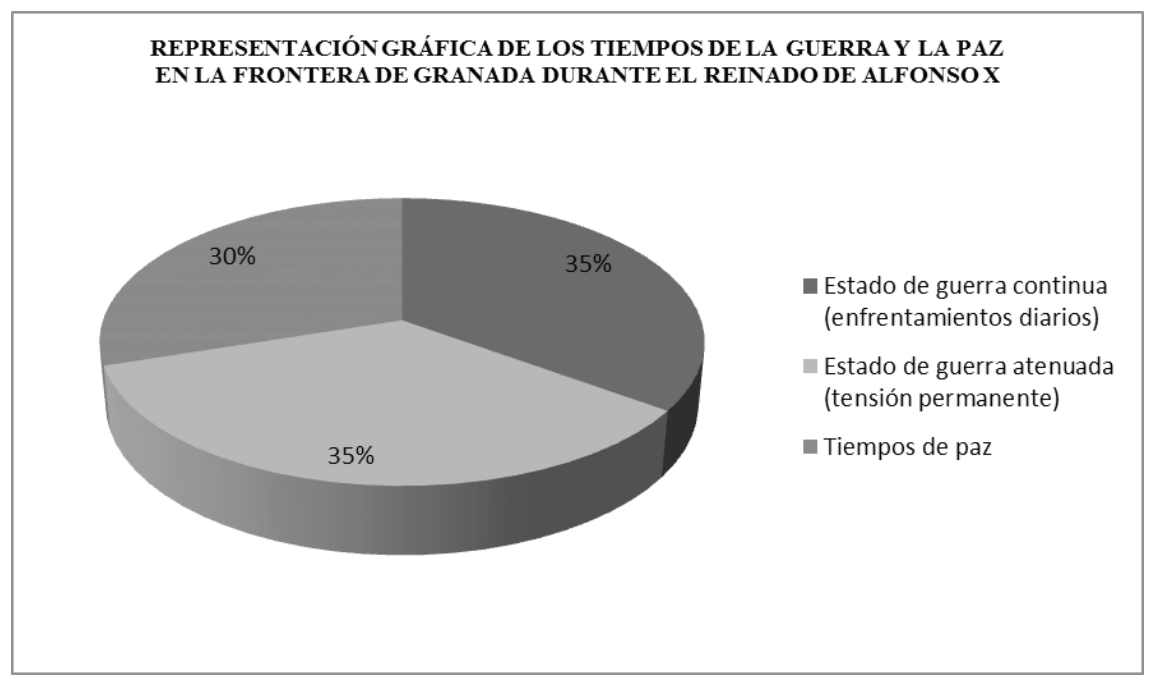

\subsection{Política y pensamiento de Alfonso X respecto al Islam}

Pero al margen de números y porcentajes -siempre fríos-, después de lo visto hasta ahora, deberíamos preguntarnos: ¿cuál fue la relación de Alfonso X con el Islam o, más bien, cómo fue visto el Islam por Alfonso X? ${ }^{158}$ Este monarca castellano de la segunda mitad del siglo XIII ha pasado a la historia como un gobernante transigente que desplegó una actitud ampliamente tolerante, a veces cercana a la admiración, hacia la cultura islámica. Sin embargo, la historiografía actual plantea la necesidad de incorporar el estudio de los conflictos bélicos a las

158. Sobre esta cuestión véase F. García Fitz. "El Islam visto por Alfonso X”, ob. cit., pp. 393-432. 
líneas de investigación abiertas sobre su persona y obra, es decir, considerar que durante el reinado del Rey Sabio la guerra no fue un estado de excepción y que el propio monarca, más allá de valorar positivamente algunos aspectos de la cultura islámica, anhelaba, en última instancia, no sólo expulsar a los musulmanes de la Península Ibérica, sino arrebatarles también el norte de África.

Sintéticamente, puede afirmarse que el legado que dejó Alfonso X en su lucha contra los moros fue: la anexión del reino de Tejada y de la comarca del Guadalete y la bahía de Cádiz (con Jerez de la Frontera y El Puerto de Santa María a la cabeza, respectivamente) en 1253; la conquista de Jerez (otra vez) en 1261; la invasión del reino de Niebla en 1262; la anexión definitiva del reino de Murcia, con la ayuda del rey aragonés Jaime I, en 1266; y, finalmente, la anulación del sistema de capitulaciones articulado por Fernando III mediante la expulsión directa o indirecta de la población mudéjar del valle del Guadalquivir, antes y después de la revuelta de $1264^{159}$.

La ocupación cristiana de todos esos territorios significó el nacimiento de un nuevo mapa político tanto para Castilla como para Al-Andalus, reducido ahora al reino de Granada, y, con ello, la aparición de nuevas fronteras, las que durante doscientos cincuenta años serán designadas en la corona de Castilla como la frontera por antonomasia.

La política de lucha contra el Islam emprendida desde el comienzo mismo de su reinado obedecía sin duda al proyecto de reconquistar España, algo que, por otra parte, venía siendo habitual en los reyes que le precedieron. El propio Rey Sabio así lo manifestó en alguna ocasión. La Primera Crónica General, por ejemplo, obra mandada compilar por él mismo, recoge que "lo que los christianos tenien en los coraçones" era "ganar dellos la tierra". Por otro lado, si las Cantigas de Santa María reflejan realmente las creencias, pensamientos, opiniones y aspiraciones personales del rey de Castilla, se puede pensar que sus deseos pasaban por destruir a los musulmanes tanto del norte de África como, sobre todo, de España, donde disfrutaban de unos territorios que, a juicio del monarca, en absoluto les pertenecían. Esta era una de las peticiones que Alfonso X hacía a la Virgen entre 1257 y $1265^{160}$ : que le diera poder y fuerza para acabar con los moros de Al-Andalus:

\footnotetext{
"e que contra os mouros que terra d'Ultramar te een e en Espanna grant part' a meu pesar, me dé poder e força pera os en deitar" ${ }^{\prime 61}$.
}

159. Desde luego, si Fernando III había llegado alguna vez a concebir un proyecto de integración política y social de la población islámica peninsular en su reino mediante el sistema de capitulaciones, Alfonso X se encargó de desmantelarlo por completo, como ya tuvimos ocasión de explicar en páginas anteriores.

160. Si, como sostienen los especialistas, esta Cantiga servía para cerrar la serie de las cien primeras, su redacción original puede fecharse entre 1257 y 1265, es decir, en un momento en el que las relaciones entre Castilla y Granada todavía no habían llegado a enrarecerse.

161. Alfonso X. Cantigas de Santa María. Madrid, 1989, Cantiga 401. 
El deseo de conquistar la tierra que los musulmanes poseían en la Península se vio cumplido en los reinos y principados arriba citados. ¿Qué ocurrió entonces con el emirato nazarí? No resulta fácil saber cuáles eran las intenciones que rey castellano tuvo desde el principio con respecto a Granada. Es posible que éstas cambiaran con el tiempo, según las circunstancias. Ahora bien, las confesiones que hizo el propio monarca en algunas de sus obras, los enfrentamientos que -sin provocación previa- emprendió contra los musulmanes peninsulares no granadinos (en un tiempo en el que todos estaban ya sometidos vasallática y tributariamente al rey de Castilla), y los intentos por debilitar al sultán de Granada mediante el persistente $\mathrm{y}$, a veces, obcecado apoyo dado a los Ashqilula, dejan entrever que Alfonso X pretendió desde el mismo momento en que subió al trono ocupar el sultanato nazarí. Es cierto que hasta 1264 los contactos entre Castilla y Granada fueron aparentemente cordiales, caracterizados incluso por el signo de la colaboración fiel entre un señor -don Alfonso- y su vasallo -Muhammad I-. Cierto es también que fue a partir de esa fecha cuando aquellos contactos experimentaron un giro radical y las relaciones entre ambos Estados se hicieron mucho más agrias, caracterizadas entonces por el enfrentamiento directo, el resentimiento, la desconfianza, el temor y la violencia. Pero, como ya se ha indicado, la actitud del Rey Sabio frente al conjunto del Islam peninsular fue permanentemente distante y agresiva, lo que nos lleva a creer que, en el fondo, la política granadina del rey de Castilla no fue otra que la expresada en la Cantiga 401: "destruir a los moros descreídos"162 de España. En la mente del monarca debió, por tanto, rondar siempre la idea de conquistar militarmente el emirato nazarí. En este sentido, la revuelta mudéjar de 1264 no hizo sino acelerar los intentos de llevar a efecto tal pretensión, dar al rey una buena excusa para iniciar la guerra y, en última instancia, variar la forma de aplicar la política militar diseñada para conquistar ese reino.

No es de extrañar, por otro lado, que ésas fueran las intenciones del monarca. Por una parte, el ideal de Reconquista se fraguó ya en los tiempos del rey astur Alfonso II y fue legado a sus descendientes hasta llegar a Alfonso X; por otra, el Rey Sabio vivió en un momento en que la idea de Cruzada estaba plenamente asentada en el imaginario colectivo de toda la Cristiandad; por último, Alfonso X fue propuesto como Rey de Romanos y no parecía conveniente optar al Imperio con musulmanes afincados en sus dominios.

En relación al primer asunto, el menosprecio que Alfonso X mostró hacia la religión islámica, desde su Profeta y doctrina hasta la comunidad que la sustentaba -menosprecio del que han dado buena cuenta historiadores como Francisco García Fitz ${ }^{163}$ o José Manuel Rodríguez García ${ }^{164}$ - se entrelazaba directamente con

162. Ibid

163. F. García Fitz. "El Islam visto por Alfonso X”, ob. cit., pp. 393-432.

164. El profesor Rodríguez García asegura que tal y como cuentan las Cantigas, narra la obra historiográfica del monarca y se deduce de su acción política, Alfonso X tenía una visión muy clara acerca de la posición de los musulmanes en su mundo: o sometidos, o expulsados o, en el peor de los casos, aniquilados. Así, la lucha contra el infiel fue, junto al Imperio, la gran obsesión del monarca, presente en su pensamiento durante todo el reinado. Véase J.M. Rodríguez García. La cruzada en tiempos de Alfonso X, ob. cit., p. 14. 
la idea de Reconquista. Para algunos autores, como Américo Castro ${ }^{165}$, Alfonso X debe ser juzgado, históricamente, como un gobernante tolerante para con los musulmanes y atribuyen su política antiislámica a la influencia que sobre él ejercieron los eclesiásticos de su Corte. Pero existen argumentos de peso -y ya los hemos aportado-que demuestran que el Rey Sabio puso en marcha contra el Islam toda una serie de campañas militares que respondían al profundo rechazo que mostró siempre hacia esa cultura y religión y, derivado de ello, a ambiciosas razones de Estado, que no eran otras que la recuperación para la Cristiandad de todos los territorios peninsulares, incluidos los del Algarve y Granada. Es más, al margen del derecho legítimo a recuperar una tierra que, según el ideal de Reconquista, pertenecía de facto a los cristianos, Alfonso X llegó a justificar la guerra contra los moros por la extrema maldad, violencia y artería con la que ellos habían arrebato a los visigodos sus posesiones territoriales algunos siglos antes, lo cual denota el deseo de venganza acumulado por el Rey Sabio ${ }^{166}$.

En relación al segundo asunto, el monarca castellano fundamenta el derecho de los cristianos a conquistar a los musulmanes las tierras o a expulsarlos de sus reinos no sólo en la tradicional reivindicación de los bienes que estos últimos habían usurpado injustamente a sus antepasados godos, sino también en otra argumentación mucho más profunda que hunde sus raíces en la Biblia y que sirve para legitimar universalmente la destrucción y el sometimiento de los islamitas: como descendientes que eran de Cam, cuya progenie fue maldecida por Noé, los musulmanes no tenían otro destino que el de convertirse en "siervos" de los hijos y herederos de los hermanos de aquél, Sem y Jafet, un enfoque muy relacionado con la ideología cruzada ${ }^{167}$. Además, para Alfonso X, el luchar contra los moros y vencerles no respondía únicamente a un objetivo político o económico -como aducen las fuentes islámicas-, sino que lo percibía esencialmente como una manera de acrecentar a la Cristiandad, idea también muy vinculada a las cruzadas ${ }^{168}$.

En efecto. No son pocos los indicios que llevan al historiador a pensar que Alfonso X fue realmente un rey cruzado. En 1252 solicitó del Papa Inocencio IV el tercio de los diezmos de las fábricas de todas las iglesias del reino, por tres años, para sufragar los gastos de la cruzada contra los sarracenos, a lo que el Sumo Pontífice accedió a comienzos de $1253^{169}$. En 1254 acordó con Enrique III de Inglaterra el reparto de los bienes inmuebles que pudieran conquistar en la cruzada que juntos proyectaban llevar a cabo "ad partes Africanas" y, tras el acuerdo, el monarca inglés solicitó del Papa autorización para conmutar el voto de ir a la cruzada a Tierra Santa por la cruzada en África ${ }^{170}$. Ese mismo año, el rey de Castilla requirió de Inocencio IV autorización para que los clérigos que acudieran a la cruzada

165. A. Castro. La realidad histórica de España. México, 1971, p. 39.

166. F. García Fitz. "El Islam visto por Alfonso X”, ob. cit., p 410.

167. F. García Fitz. "El Islam visto por Alfonso X”, ob. cit., p. 409.

168. F. García Fitz. "El Islam visto por Alfonso X”, ob. cit., p. 415.

169. Diplomatario, doc. núm. 10 (p. 10). Ese tercio de los diezmos eran las llamadas tercias reales.

170. Diplomatario, doc. núm. 131 (pp. 135-136). 
contra los sarracenos en África percibieran íntegramente el importe de sus beneficios, a lo que el Papa accedió también ${ }^{171}$. Como ya vimos, en junio de 1264 el rey comunicaba a don Pedro Lorenzo, obispo de Cuenca, a don Andrés, obispo de Sigüenza y a don Martín, obispo de Segovia, la sublevación de los mudéjares con la ayuda del emir de Granada y, sin autorización papal ${ }^{172}$, les pidió que predicasen la cruzada ${ }^{173}$. Al año siguiente, solicitó de Clemente IV la predicación de la bula de cruzada para luchar contra los moros, y el Papa dio su aprobación ordenando a don Remondo, arzobispo de Sevilla, que se predicara ${ }^{174}$. Diez años más tarde, en 1275, Alfonso X volvía ordenar a don Remondo la predicación de la cruzada para hacer frente al poder benimerín y para ello adjuntó la bula que recibiera en 1265 . En cualquier caso, en el mes de julio Gregorio X ya había reconocido el carácter cruzado de esta campaña y en marzo de 1276 Inocencio V otorgó específicamente a favor suyo la bula cruzada "Exurgat Deus"175. Finalmente, en 1279 el Rey Sabio ordenó al concejo de Burgos que atendieran lo que el arzobispo de Sevilla les diría "sobre el fecho de la cruzada" 176 y todavía en 1280 ésta se seguía predicando a fin de detener la invasión benimerín.

171. Diplomatario, doc. núm. 145 (p. 155).

172. Durante los siglos XI y XII no estuvo muy claro canónicamente quién tenía la potestad de conceder las indulgencias plenarias o cruzadas. Sin embargo, a partir de 1215, tanto a través de los cánones conciliares como de las bulas papales, se estableció claramente que era el Papa el único con potestad para emitirlas y fijarlas, para luego delegar en su legado u obispos locales la predicación sobre el terreno. En las cartas enviadas a los obispos de Segovia, Cuenca y Sigüenza en 1264 el monarca adjuntó dos bulas papales: una que Inocencio IV había dado en Lyon el 25 de mayo de 1246 y otra que Alejandro IV expidió en Anagni el 27 de agosto de 1259. Pero no hubo un consentimiento papal expreso en 1264, liderando la Iglesia Urbano IV. Es evidente que la autorización de Alfonso X a sí mismo, ordenando una nueva predicación, estaba en contra de toda la práctica canónica y de los diferentes escritos emanados desde la curia papal. ¿Por qué entonces el rey ordenó una predicación cruzada, con lo que ello implicaba de conceder perdones eclesiásticos, sin el permiso del Pontífice? Es una pregunta difícil de responder. José Manuel Rodríguez García habla, desde luego, de un "hecho inédito" en la historia del movimiento cruzado. Una razón posible es que no había tiempo que perder en el sometimiento de la revuelta mudéjar. Otra, quizás más convincente, está relacionada con la concepción que el rey tenía acerca del origen divino del poder. En este sentido, Alfonso X defendió la absoluta independencia del poder real, ya que, en lo temporal, el rey era vicario de Dios en la tierra y no estaba sometido a nadie más que a Él. En esto, y en otros muchos aspectos, el pensamiento político del Rey Sabio estaba impregnado de la ideología que conocemos con el nombre de "teoría de las dos espadas", que reclamaba la independencia del poder temporal respecto al espiritual, puesto que ambos procedían directamente de Dios y tenían sus propios cometidos y campo de actuación. Véase J.M. Rodríguez García. Ideología cruzada en el siglo XIII. El Puerto de Santa María, 2014, pp. 23, 142 y 143, y M. González Jiménez, Alfonso X el Sabio, 1252-1284, ob. cit., p. 198.

173. Diplomatario, doc. núm. 286 (pp. 313-316) y doc. núm. 287 (p. 316).

174. Diplomatario, doc. núm. 307 (p. 331). En la bula de cruzada de 1265 Clemente IV alertaba de que una derrota en Hispania podía poner en peligro a toda la Cristiandad.

175. J.M. Rodríguez García. Ideología cruzada en el siglo XIII, ob. cit., pp. 205-206.

176. En la carta que Alfonso X envió al concejo de Burgos, en la que defendía la labor predicadora y recaudatoria del arzobispo de Sevilla, el monarca les animaba a participar en la cruzada para que sus caballeros pudieran así "saluar las almas et onrrar los cuerpos et guardar nuestra tierra". En este sentido, los burgaleses, como el resto de hispanos, tenían la suerte de poder disfrutar de esta vía de salvación muy cerca de su casa, sin la necesidad de trasladarse hasta el otro extremo del Mediterráneo: "estando casi a la puerta de casa, podían adquirir la gloria del reino celestial", era uno de los estímulos utilizados por los predicadores de la época para incitar a los caballeros a participar en la cruzada. Véase 
No debe caber duda, por tanto, del espíritu cruzado que el rey de Castilla albergaba en su corazón. Está claro que no se puede entender la Reconquista, en su conjunto, como una sucesión de Cruzadas, ya que éstas fueron determinadas campañas limitadas y autorizadas por el Santo Padre. Sin embargo, el fenómeno de la Reconquista está plagado de empresas de tintes cruzados y, tal y como hicieron sus antepasados, Alfonso X también se benefició puntualmente de este recurso para ultimar su proyecto político y militar. Ello explicaría que recurriera al llamado negotio Christi en 1254, cuando se empezó a fraguar el fecho de allende ${ }^{177}$, en 1264 y 1265, tras producirse la revuelta de mudéjares y granadinos, y en 1275, 1276 y 1279 , a raíz de las continuas invasiones benimerines.

Por otra parte, ya indicamos al comienzo del presente artículo que la entrega de señoríos en la frontera de Granada respondía al compromiso regio de distribuir entre los vencedores las recompensas de que se habían hecho acreedores por su esfuerzo y tenacidad en la conquista de la Andalucía bética, pero también, y sobre todo, a la intención del rey de defender un territorio recién invadido y por ello constantemente amenazado. La militarización de la frontera, implementada gracias a la colaboración de la nobleza, ha de entenderse en consecuencia como un apoyo del que se vale el monarca al no disponer de fuerzas suficientes para la defensa de las fronteras meridionales de su reino. Pero resulta significativo que el sector nobiliario al que se le confiara un mayor número de encomiendas fronterizas fuera el de las órdenes militares. No es casualidad. Para Alfonso X, como para el resto de la nobleza del reino, la lucha contra el Islam era en sí una cruzada, razón por la cual el monarca contó para su causa, en primer lugar, con las órdenes militares, la fuerza más capacitada para la defensa de la región y, sin lugar a dudas, la más vinculada ideológicamente al espíritu cruzado ${ }^{178}$.

En definitiva, Alfonso X nunca estuvo en Tierra Santa, pero no por ello debemos descartarlo como rey cruzado. A fin de cuentas, en el siglo XIII no sólo recibían indulgencias plenarias los caballeros que luchaban en Jerusalén. Es más, junto con el de Tierra Santa y el Báltico, la Península Ibérica y el norte de África se convirtieron pronto en un escenario cruzado preferente ${ }^{179}$. Y, en todo caso, si

Diplomatario, doc. núm. 445 (p. 466) y J.M. Rodríguez García. La cruzada en tiempos de Alfonso X. ob. cit., pp. 139-140.

177. Como ya advertimos en la nota 22, Alfonso X asumió el ideal de su padre de continuar la conquista por el norte de África, heredando así el modelo paterno de un rey cruzado y, por tanto, guerrero. Para Rodríguez García la campaña de África, que tuvo un carácter cruzado, se justifica en base a tres objetivos, a cual más importante: uno de carácter histórico, recuperar las antiguas tierras que habían pertenecido a la Hispania romana cristiana y al reino visigodo; otro de connotaciones geoestratégicas, controlar la zona de Estrecho para evitar el continuo traspaso de tropas musulmanas a la Península desde el continente africano; finalmente, un tercer objetivo de naturaleza ideológica, abrir una nueva vía para los cruzados penetrando por el Magreb para, desde ahí, continuar hacia Oriente a fin de liberar los Santos Lugares. Véase J.M. Rodríguez García. Ideología cruzada en el siglo XIII, ob. cit., pp. 110-111.

178. J.M. Alcántara Valle. "Nobleza y señoríos en la frontera de Granada durante el reinado de Alfonso X. Aproximación a su estudio", ob. cit., p. 232.

179. El impacto de la sublevación mudéjar, que se había sentido a nivel europeo, llevaron tanto a Alfonso X como al propio Papado a resaltar que la lucha en la Península Ibérica contra los musulma- 
el Rey Sabio nunca contempló la posibilidad de luchar en Tierra Santa no fue por mero desinterés sino, muy probablemente, por la misma razón por la que Fernando III había rechazado de su primo Luis IX de Francia la oferta que éste le hizo para que se uniera a su cruzada: "no faltan musulmanes en mi tierra"180.

Si la idea de Cruzada está directamente relacionada con la de Reconquista, la política desplegada por Alfonso X para ser proclamado Emperador de Occidente hay que ponerla en relación directa con las cruzadas. Por un lado, el rey de Castilla estaba obligado a expulsar a los musulmanes de sus territorios porque hacia 1252 toda la banda castellana de la frontera nazarí era predominantemente mudéjar y ello constituía un peligro potencial para el reino en el futuro, pero también, y básicamente, porque no resultaba nada beneficioso para quien aspiraba a convertirse en Rey de Romanos el mantener súbditos musulmanes en sus dominios. Por otro, el fecho de África podía suponer una baza muy útil de cara a la consecución del fecho del Imperio. Así es. El prestigio de encabezar una cruzada en Occidente contra los musulmanes "de aquende" (granadinos) y de "allende" (Berbería), en un momento en que las cruzadas en Tierra Santa no estaban alcanzando los éxitos deseados, constituía un aval extraordinario de cara a sus pretensiones de ser proclamado Emperador. En esta dirección, Alfonso X, que aspiraba con ahínco a convertirse en la cabeza política de la Cristiandad y sabedor del efecto que una operación como aquélla tendría en todo el Occidente cristiano, no podía dejar de percibir la potencialidad propagandística de ese proyecto ${ }^{181}$.

Concluimos. Del medio centenar de Cantigas donde aparecen musulmanes, en la inmensa mayoría - prácticamente el $85 \%$ de los casos- éstos son presentados como enemigos de la Cristiandad. Desde luego, si esta fue la obra más personal de Alfonso X, entonces no puede dudarse de que el Rey Sabio percibió siempre a los musulmanes como adversarios y antagonistas de los que, salvo en muy contadas excepciones, sólo cabía esperar la guerra y a los que únicamente cabía combatir. Ellos eran los enemigos políticos y militares por antonomasia, pero también los principales enemigos religiosos ${ }^{182}$. Por eso debe subrayarse que aquellos musul-

nes no había que entenderla como una lucha localizada, sino como un problema que afectaba a toda la Cristiandad y que, por ende, podía redundar a la larga en la liberación de los Santos Lugares. En este sentido, a partir de 1265 los papas reiteraron la creencia de que una vigorosa acción en España podría contribuir a la recuperación de Tierra Santa (J.M. Rodríguez García. Ideología cruzada en el siglo XIII, ob. cit., p. 164).

180. La cita la recoge José Manuel Rodríguez García en Ideología cruzada en el siglo XIII, ob. cit., p. 91 .

181. De hecho, el Rey Sabio no dejó pasar la oportunidad de remitir cartas a papas y reyes europeos informando de cada uno de sus proyectos cruzados y de sus victorias militares frente a los musulmanes.

182. El propio Rey Sabio afirma en las Partidas que "los reyes de España" tenían derecho de intervenir en las elecciones episcopales "porque ganaron las tierras de los moros et fizieron las Mezquitas Iglesias: e echaron de ý el nome de Mahoma e metieron ý el nome de Nuestro Señor Iesv Christo" (Partida I, título V, ley XVIII). Por otra parte, la versión castellana del epitafio que Alfonso X mandó colocar en la tumba de su padre dice, refiriéndose al Rey Santo, “...el que mas temie a Dios e el que mas le fazía servicio, e el que quebrantó e destruyó a todos sus enemigos...", en clara alusión a los enemigos de Dios, que no eran otros que los musulmanes. 
manes hacia los que mostró una actitud más favorable, compasiva o humana fueron individuos que terminaron convirtiéndose al Cristianismo o reconociendo el poder superior de la Virgen María ${ }^{183}$.

En las Cantigas, a fin de demostrar la crueldad de aquellos enemigos radicales, se describen pormenorizadamente los daños causados por los ejércitos norteafricanos, especialmente por los benimerines que corrieron Andalucía durante los años finales de su reinado. Sin embargo, cuando se trata de relatar las operaciones militares emprendidas por los cristianos contra sus vecinos musulmanes, causantes también de daños y destrucciones, el monarca no sólo no lamenta ni condena las incursiones, sino que muestra su satisfacción y se alegra de aquellos comportamientos. Y es que la guerra contra el Islam formaba parte, en la percepción alfonsí, del código de buenas costumbres del caballero, y, lo que es más importante, constituía una de las mejores formas de demostrar el amor a Dios y a su Madre. Quizás por esto, como se afirma en la Cantiga 63, el Rey Sabio "nunca con mouros quiso aver paz" ${ }^{184}$.

Nadie discute que hubo préstamos, transferencias e influencias culturales en la frontera de Granada, pero nunca respeto, convivencia ni tolerancia, si con ello nos referimos a la plena aceptación de las creencias y costumbres del otro. Y si bien se firmaron treguas, tratados de paz y alianzas entre moros y cristianos, y existió incluso la figura del alfaqueque y del trujamán, que redimían a los cautivos apresados por el enemigo, no debemos perder de vista que todo aquello era también consecuencia directa de un estado de guerra continua. Las tropas cristianas fueron derrotadas en las cuatro batallas que tuvieron lugar en la frontera de Granada durante el reinado de Alfonso X (Écija, Martos, Algeciras y Moclín), pero el Rey Sabio pudo anexionar a Castilla, definitivamente, cuatro extensas regiones de un altísimo valor estratégico y económico: el reino de Tejada, la comarca del Guadalete y la bahía de Cádiz, el reino de Niebla y el reino de Murcia. Ése fue legado militar que dejó monarca, y éste, nuestro balance del gobierno de un Rey Sabio, que supo ser también, tal y como el contexto y las circunstancias exigían, un rey estratega, guerrero y cruzado.

\section{BIBLIOGRAFÍA}

Alcántara Valle, José María. "Nobleza y señoríos en la frontera de Granada durante el reinado de Alfonso X. Aproximación a su estudio", Vínculos de Historia, Revista del Departamento de Historia de la Universidad de Castilla-La Mancha, 2 (2013), pp. 207-232.

Alfonso X. Las Partidas. Madrid, 1984. Partida I, II y VII.

—. Cantigas de Santa María. Madrid, 1989, Cantigas 63, 348 y 401.

183. F. García Fitz. "El Islam visto por Alfonso X", ob. cit., p. 411, 418 y 419.

184. F. García Fitz. "El Islam visto por Alfonso X”, ob. cit., pp. 411-415. 
Argente del Castillo Ocaña, Carmen. "Los cautivos en la frontera entre Jaén y Granada", IV Coloquio de Historia Medieval Andaluza. Relaciones exteriores del Reino de Granada. Almería, 1988, pp. 211-225.

- " "Las actividades agroganaderas en la Frontera", II Estudios de Frontera. Actividad y vida en la frontera (en memoria de don Claudio Sánchez Albornoz). Jaén, 1998, pp. 73-97.

—. "Las relaciones de convivencia a través de los tratados de paz", III Estudios de Frontera. Convivencia, defensa y comunicación en la frontera (homenaje a don Juan de Mata Carriazo). Jaén, 2000, pp. 81-102.

Ayala Martínez, Carlos de. "Las órdenes militares castellano-leonesas y la acción de frontera en el siglo XIII", Ayala Martínez, Carlos de et al. (ed.). Identidady representación de la frontera en la España medieval (siglos XI-XIV). Madrid, 2001.

Cabrera, Emilio. "Un pionero de la repoblación nobiliaria en los siglos XIII y XIV. Fernando Díaz Carrillo, señor de Santa Eufemia", VI Estudios de Frontera. Población y poblamiento en la Frontera (homenaje a don Manuel González Jiménez). Jaén, 2006, pp. 156-157.

Carmona Ruiz, María Antonia. "La actividad ganadera en la Banda Morisca", García Fernández, Manuel (dir.). La Banda Morisca durante los siglos XIII, XIV y XV. Actas de las II Jornadas de Temas Moronenses. Morón de la Frontera, 1996, pp. 157-173.

Carriazo y Arroquia, Juan de Mata. En la frontera de Granada. Sevilla, 1971.

Castro, Américo. La realidad histórica de España. México, 1971.

García Fernández, Manuel. Andalucía: Guerra y Frontera, 1312-1350. Sevilla, 1990.

—. "En la frontera de Granada. La paz y la guerra en la campiña sevillana (siglos XIII-XV)", La campiña sevillana y la frontera de Granada (siglos XIII-XV). Estudios sobre poblaciones de la Banda Morisca. Sevilla, 2005, pp. 67-76.

—. "Sobre la alteridad en la frontera de Granada. Una aproximación al análisis de la guerra y la paz (siglos XIII-XV)". Revista da Facultade de Letras HISTÓRIA. Porto, 2005, III Série, vol. 6, pp. 213-235.

—. "Alfonso X y la invención de la frontera de Granada (1252-1267)", González Ferrín, Emilio (coord.). Encrucijada de culturas: Alfonso Xy su tiempo (homenaje a Francisco Márquez Villanueva). Sevilla, 2014, pp. 249-266.

García Fitz, Francisco. "Los acontecimientos político-militares de la Frontera en el último cuarto del siglo XIII", Revista de Historia Militar, 64 (1988), pp. 9-71.

—. "La defensa de la frontera del Bajo Guadalquivir ante las invasiones benimerines del siglo XIII", Viguera Molins, María Jesús (ed.). Las relaciones de la Península Ibérica con el Magreb (siglos XIII-XVI). Madrid, 1988, pp. 275-323.

—. "La frontera castellano-granadina a fines del siglo XIII", Segura Graíño, Cristina (ed.). IV Coloquio de Historia Medieval Andaluza. Relaciones exteriores del Reino de Granada. Almería, 1988, pp. 23-35. 
-. "Alfonso X, el reino de Granada y los Banu Asqilula. Estrategias políticas de disolución durante la segunda mitad del siglo XIII". Anuario de Estudios Medievales, 27 (1997), pp. 215-237.

—. "Estrategias internacionales en el contexto de sociedades de frontera. La amenaza africana en las relaciones castellano-andalusíes, siglos XI al XIII", II Estudios de Frontera. Actividad y vida en la frontera (en memoria de don Claudio Sánchez Albornoz). Jaén, 1998, pp. 269-292.

- Castilla y León frente al Islam. Estrategias de expansión y tácticas militares (siglos XI-XIII). Sevilla, 1998.

-. "Una frontera caliente. La guerra en las fronteras castellano-musulmanas (siglos XI-XIII)", Ayala Martínez, Carlos de et al. (ed.). Identidad y representación de la frontera en la España medieval (siglos XI-XIV). Madrid, 2001, pp. 159-179.

- Relaciones políticas y guerra. La experiencia castellano-leonesa frente al Islam. Siglos XI-XIII. Sevilla, 2002.

-. "Alfonso X y sus relaciones con el Emirato granadino: política y guerra", Alcanate. Revista de Estudios Alfonsies, 4 (2004-2005), El Puerto de Santa María, 2005, pp. 35-77.

- Las Navas de Tolosa. Barcelona, 2005.

—. "El Islam visto por Alfonso X", Cristianos y musulmanes en la Península Ibérica: la guerra, la frontera y la convivencia. XI Congreso de Estudios Medievales (2007). León, 2009, pp. 393-432.

García Guzmán, María del Mar. El Adelantamiento de Cazorla en la Baja Edad Media. Un señorío eclesiástico en la frontera castellana. Cádiz, 1985.

—. Colección Diplomática del Adelantamiento de Cazorla (1231-1495). Cádiz, 1991.

García Sanjuán, Alejandro. "Consideraciones sobre el pacto de Jaén de 1246”, González Jiménez, Manuel (coord.). Sevilla, 1248. Congreso Internacional Conmemorativo del 750 Aniversario de la Conquista de la Ciudad de Sevilla por Fernando III, Rey de Castilla y León. Madrid, 2000, pp. 715-722.

González Jiménez, Manuel. "Esclavos andaluces en el Reino de Granada”, Actas del III Coloquio de Historia Medieval Andaluza. La sociedad medieval andaluza: grupos no privilegiados. Jaén, 1984, pp. 327-338.

- "Población y repartimiento de Écija", Homenaje al Profesor Torres Fontes, vol. I. Murcia, 1987, pp. 691-711.

—. En torno a los orígenes de Andalucía. La repoblación del siglo XIII. Sevilla, 1988.

-. "Jerez de la Frontera en el siglo XIII", Actas de las II Jornadas de Historia de Jerez. Jerez medieval. Jerez de la Frontera, 1990, pp. 11-19.

-. (ed.). Diplomatario Andaluz de Alfonso X. Sevilla, 1991.

—. "Relaciones de las Órdenes Militares Castellanas con la Corona", Historia. Instituciones. Documentos, 18 (1991), pp. 209-222.

- y García Fernández, Manuel (ed.). Actas Capitulares de Morón de la Frontera (1402-1426). Sevilla, 1992. 
-. Alfonso X el Sabio, 1252-1284. Palencia, 1993.

- " "Andalucía, Granada y el Estrecho de Gibraltar en tiempos de Alfonso X", Actas del II Congreso Internacional "El Estrecho de Gibraltar”. Madrid, 1995, vol. III, pp. 1-25.

—. "Osuna en el siglo XIII”, Iglesias Rodríguez, Juan José y García Fernández, Manuel (coord.). Osuna entre los tiempos medievales y modernos (siglos XIIIXVIII). Sevilla, 1995, pp. 39-51.

—. "De la expansión a la crisis: la sociedad andaluza entre 1225 y 1350", Toro Ceballos, Francisco y Rodríguez Molina, José (coord.). Estudios de Frontera. Alcalá la Real y el Arcipreste de Hita. Jaén, 1996, pp. 211-238.

—. "Alfonso X y las minorías confesionales de mudéjares y judíos", Rodríguez Llopis, Miguel (coord.). Alfonso X. Aportaciones de un rey castellano a la construcción de Europa. Murcia, 1997, pp.71-90.

—. "Cortes de Sevilla de 1261". Historia. Instituciones. Documentos, 25 (1998), pp. 295-311.

-. Andalucía a debate y otros estudios. Sevilla, 1998.

-. (edición, transcripción y notas). Crónica de Alfonso X. Según el Ms. II/2777 de la Biblioteca del Palacio Real (Madrid). Murcia, 1999.

—. "Una noble çibdat e bona: fundación y poblamiento de El Gran Puerto de Santa María por Alfonso X El Sabio", Alcanate. Revista de Estudios Alfonsíes, 1 (1998-1999), El Puerto de Santa María, 1999, pp. 19-28.

-. "Conquista y repoblación de Arcos de la Frontera", Actas del I Congreso de Historia de Arcos de la Frontera (congreso conmemorativo del 750 aniversario de la conquista de la ciudad por Alfonso X el Sabio, 1253-2003). Cádiz, 2003, pp. 11-29.

—. "Andalucía, una realidad histórica", II Jornadas sobre el habla andaluza. El español hablado en Andalucía. Estepa, 2003, pp. 27-43.

-. Alfonso X el Sabio. Barcelona, 2004.

-. "Orígenes medievales de la Universidad de Sevilla", Serrera Contreras, Ramón María y Sánchez Mantero, Rafael (coord.). V Centenario. La Universidad de Sevilla (1505-2005). Sevilla, 2005, pp. 1-17.

-. Fernando III el Santo. El rey que marcó el destino de España. Sevilla, 2006.

-. "La tenencia de castillos en tiempos de Alfonso X", VI Estudios de Frontera. Población y poblamiento en la Frontera (homenaje a don Manuel González Jiménez). Jaén, 2006, pp. 297-311.

_. La repoblación del Reino de Sevilla en el siglo XIII. Granada, 2008.

- y Carmona Ruiz, María Antonia. Documentación e itinerario de Alfonso X el Sabio. Sevilla, 2012.

González Mínguez, César. Poder real y poder nobiliar en la Corona de Castilla (1252-1369). Bilbao, 2012.

Hinojosa, Gonzalo de la. Estoria del fecho de los godos, Marqués de la Fuensanta del Valle. Colección de Documentos Inéditos para la Historia de España. Madrid, 1893, vol. CVI. 
Ibn Abi Zar. Rawd al-Qirtas (traducción y anotaciones de Huici Miranda, Ambrosio). Valencia, 1964, vol. II.

Ibn Idari, Al-Bayan Al-Mugrib, Huici Miranda, Ambrosio (edición y traducción). Colección de Crónicas Árabes de la Reconquista. Tetuán, 1954, vol. III.

Jaime I. Llibre dels fets, Barcelona, 1991.

Ladero Quesada, Miguel Ángel. Los señores de Andalucía. Investigaciones sobre nobles y señoríos en los siglos XIII a XV. Cádiz, 1998.

Manzano Rodríguez, Miguel Ángel. La intervención de los benimerines en la Península Ibérica. Madrid, 1992.

Martínez Díez, Gonzalo. Fernando III, 1217-1252. Palencia, 1993.

Menéndez Pidal, Ramón (ed.). Primera Crónica General de España. Madrid, 1977, tomo II.

O'Callaghan, Joseph F. El Rey Sabio. El reinado de Alfonso X de Castilla (traducción de Manuel González Jiménez). Sevilla, 1996.

Pérez Castañera, Dolores María. Enemigos seculares. Guerra y treguas entre Castilla y Granada (1246-1481). Madrid, 2013.

Puyol, Julio. "Crónicas Anónimas de Sahagún”, Boletín de la Real Academia de la Historia, LXXVII, 1920.

Rodríguez García, José Manuel. "La marina alfonsí al asalto de África (12401280). Consideraciones estratégicas e historia", Revista de Historia Naval, 85 (2004), pp. 27-56.

- Ideología cruzada en el siglo XIII. Una visión desde la Castilla de Alfonso X. El Puerto de Santa María, 2014.

-. La cruzada en tiempos de Alfonso X. Madrid, 2014.

Rodríguez Molina, José. "La frontera de Granada, siglos XIII-XV”, Estudios de Frontera. Alcalá la Real y el Arcipreste de Hita. Jaén, 1996, pp. 503-560.

—. "Relaciones pacíficas en la frontera con el Reino de Granada", Actas del Congreso La Frontera Oriental Nazarí como sujeto histórico (siglos XIII-XVI). Almería, 1997, pp. 257-290.

-. "Convivencia de cristianos y musulmanes en la frontera de Granada", La Paz en la Historia. Granada, 2000, pp. 189-228.

—. La vida de moros y cristianos en la frontera. Alcalá la Real, 2007.

Sánchez Saus, Rafael. "El Almirantazgo de Castilla hasta don Alonso Jofré Tenorio: redes de parentesco y tradición familiar", González Jiménez, Manuel y Montes Romero-Camacho, Isabel (ed.). La Península Ibérica entre el Mediterráneo y el Atlántico. Siglos XIII-XV, Sevilla-Cádiz, 2006.

Sanz Fuentes, María Josefa. "Repartimiento de Écija". Historia. Instituciones. Documentos, 3 (1976), pp. 533-551.

Torres Delgado, Cristóbal. El antiguo reino nazarí de Granada (1232-1340), Granada, 1974.

Torres Fontes, Juan. Fueros y Privilegios de Alfonso X, Colección de Documentos para la Historia del Reino de Murcia. Murcia, 1973, vol. III.

—. "La Orden de Santa María de España”, Miscelánea Medieval Murciana, 1977, vol. 3, pp. 74-118. 
- El concejo de Cartagena en el siglo XIII. Murcia, 1977.

—. La reconquista de Murcia en 1266 por Jaime I. Murcia, 1987.

Valdeón Baruque, Julio. "Alfonso X y la convivencia cristiano-judía-islámica". Estudios Alfonsíes. Lexicografía, lírica, estética y política de Alfonso X el Sabio. Granada, 1985, pp. 167-177.

Vázquez Campos, Braulio. "Sobre el origen del cargo de Adelantado de la Frontera”, González Jiménez, Manuel (coord.). Sevilla, 1248. Congreso Internacional Conmemorativo del 750 Aniversario de la Conquista de la Ciudad de Sevilla por Fernando III, Rey de Castilla y León. Madrid, 2000, pp. 813-820.

—. "Sobre los orígenes del Adelantamiento de Andalucía", Historia. Instituciones. Documentos, 27 (2000), pp. 333-373.

- " "Frontera y adelantamientos en época de Alfonso X", Historia. Instituciones. Documentos, 30 (2003), pp. 513-535.

-. Los adelantados mayores de la Frontera o Andalucía (siglos XIII-XIV). Sevi1la, 2006.

- Adelantados y lucha por el poder en el reino de Murcia. Alcalá la Real (Jaén), 2009.

Fecha de recepción del artículo: marzo de 2015

Fecha de aceptación y versión final: septiembre de 2015 